\title{
BETTER LATE THAN NEVER: \\ HOW THE U.S. GOVERNMENT CAN AND SHOULD USE BAYH-DOLE MARCH-IN RIGHTS TO RESPOND TO THE MEDICINES ACCESS CRISIS
}

\author{
JENNIfER PenMan* ANd Fran Quigley ${ }^{+}$
}

The Bayh-Dole Act of 1980 allowed private patenting of inventions discovered with federally-funded research. Congress balanced that significant benefit to private entities by empowering the government to "march in" and grant a license to another manufacturer when the license holder has not made the invention available to the public on reasonable terms. Bayh-Dole also allows march-in when necessary to alleviate health or safety needs. Remarkably, federal agencies have not once exercised these rights since Bayh-Dole's passage, even in the face of significant problems with access to medicines discovered with federal funding. This Article argues that the current medicines pricing and access crisis, highlighted by the inaccessibility of an effective prostate cancer drug discovered by government funding, calls for the U.S. agencies to finally fulfill the terms of the Act.

\section{TABLE OF CONTENTS}

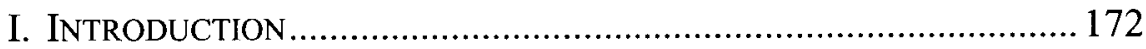

II. OVERVIEW OF THE BAYH-DOLE ACT ............................................ 173

A. Perceived Need for Incentives to Develop FederallySupported Inventions....................................................... 174

1. Is this premise correct? ............................................ 175

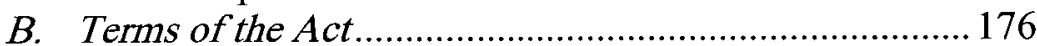

1. March-In Rights ...................................................... 177

* Attorney at Law, Penman Legal, LLC; J.D., Indiana University McKinney School of Law. We would like to thank Knowledge Ecology International, especially Andrew Goldman and James Love, for their insight and research on this topic, and for their encouragement in the process of developing this article.

+ Clinical Professor of Law, Director, Health and Human Rights Clinic, Indiana University McKinney School of Law; Coordinator, People of Faith for Access to Medicines. 
2. Royalty-Free Licenses...............................................178

3. Other Federal Licensing Rights .................................. 179

III. Pricing, Health Needs, And March-In Under BayhDOLE

A. Legislative Intent on March-In Authority and Reasonable Price.

B. Other Analyses of March-In Rights

C. Health and Safety Needs and March-In.

IV. THE IMPACT OF BAYH-DOLE ON THE AVAILABILITY OF

FEDERALLY-FUNDED INVENTIONS

A. Has Bayh-Dole Spurred Innovation in Medicines?.

B. Has Bayh-Dole Improved Access to Federally-Funded Inventions?

C. Has Bayh-Dole Had a Positive Impact on Academic Institutions and Research Priorities?

D. Petitions Filed for Federal Licensing Under the BayhDole Act.

E. The Pharmaceutical Industry's Relationship with Federal Health Agencies.

A. The Discovery and Development of Xtandi ....................203

1. NIH and DoD Funding of Xtandi Research ...............204

2. University-Held Patents and Transfer of Licenses....205

a. Xtandi as Example of How Bayh-Dole has

Transformed Discovery and Licensing...............206

VI. The XTANDI AvAILABILITY CRISIS ..............................................2208

A. Costs to Medicare and other Federal Programs.............. 208

B. Lack of Access to Patients in Private Insurance Plans ... 210

VII. U.S. GOVERNMENT RESPONSE TO XTANDI CRISIS

A. Congressional Requests to NIH and HHS .....................212

B. Xtandi Petition to NIH, DoD, and HHS under BayhDole

1. Offer by Generic Manufacturer.................................214

C. Government Responses ..................................................214

VIII. CONCLUSION 216

\section{INTRODUCTION}

The Bayh-Dole Act of 1980 states a clear objective to "protect the public against ... unreasonable use of inventions" that owe their 
origins to federally-funded research. The Act empowers the government to "march in" and grant a license to another manufacturer if the license holder has not made the invention available to the public on reasonable terms or if the action is necessary to alleviate health or safety needs.

Yet, decades of determined advocacy by holders of licenses on federally-funded inventions, in particular holders of medicine patents, has led to relevant federal agencies not even once exercising the rights granted to them by Congress, even in the face of significant problems with access to medicines discovered with federal funding. This Article outlines the clear language of the Act, and the legislative intent behind it, and argues that the current medicines pricing and access crisis calls for the U.S. government to finally fulfill the terms of the Act.

A review of the case of the highly effective prostate cancer drug enzalutimade, marketed under the name Xtandi, provides an instructive case study. Xtandi is a medicine discovered with federal funding, now patented by private entities who charge exorbitant prices to the federal government and taxpayer patients who paid for its discovery. The U.S. should exercise its Bayh-Dole march-in rights for Xtandi, and in other cases where medicine whose discovery was federally-funded is not available on reasonable terms.

\section{OVERVIEW OF THE BAYH-DOLE ACT}

The University and Small Business Patent Procedures Act of $1980,{ }^{1}$ commonly referred to as the Bayh-Dole Act, was born out of a worry that the United States was falling behind in innovation and that there was not a standard procedure for determining ownership of intellectual property that was developed under federal funding. ${ }^{2}$ Before 1980 , procedure on electing title to the invention was largely left up to the federal agencies. ${ }^{3}$ Agencies that provided funding had differing policies. Some retained ownership, making the invention public domain, while others allowed for the inventors to take title. ${ }^{4}$ Procedures became standardized with the passage of the Bayh-Dole

1. 35 U.S.C. $\S \S 200-212$.

2. Ryan Whalen, The Bayh-Dole Act \& Public Rights in Federally Funded Inventions: Will the Agencies Ever Go Marching In, 109 NW. U. L. REV. 1083, 1087 (2015).

3. Lorelei Ritchie de Larena, The Price of Progress: Are Universities Adding to the Cost, 43 Hous. L. REV. 1373, 1378 (2007).

4. Id. 
Act. Since 1980, entities that have received federal funding in the process of discovery and invention have been allowed to patent their inventions after giving notice to the government. ${ }^{5}$ The Act also authorized the federal government to retain certain rights in the invention. These include march-in rights and royalty free licenses, which will be discussed in greater detail below.

\section{A. Perceived Need for Incentives to Develop Federally- Supported Inventions}

The Act was named after two of its main proponents, Senators Birch Bayh (D-Ind.) and Robert Dole (R-Kan.). It was signed into law by President Jimmy Carter in December 1980. Section 200 of the Act describes the policy and objective behind the Act in full, but can be briefly summarized as the intent on the behalf of Congress to utilize the patent system in the U.S. to foster collaboration between private industry and nonprofit organizations in order to fully commercialize inventions made under federal funding, and to ensure that such inventions are available to the public. ${ }^{6}$ In 1983, President Ronald Reagan furthered this initiative by way of a presidential memorandum that expanded those allowed to patent a federally funded invention to include federal government contractors. ${ }^{7}$ Previously, as its formal title implies, the Act only reached nonprofit organizations, such as universities, and small businesses. ${ }^{8}$

In the late 1970 s, when the bill was being drafted, approximately fifty percent of all U.S. scientific research was federally funded. ${ }^{9}$ The majority of the funding agencies required that patent ownership rights were conceded to the federal government, regardless of the amount of federal funding contributed. ${ }^{10}$ Yet, while the government owned an extensive catalog of patents, only approximately four percent of those patents were actually licensed. ${ }^{11}$ Legislators sought to remedy this

5. See Id. at 1375 (discussing 35 U.S.C. $\S 202(\mathrm{c})(3)$ and "giving notice" to the government).

6. 35 U.S.C.A. $\S 200$ (West 2000)

7. JOHN R. THOMAS, CONG. RESEARCH SERV., R44597, MARCH-IN RIGHTS UNDER THE BAYH-DOLE ACT 6 (2016).

8. Id.

9. Whalen, supra note 2 , at 1087

10. Id. at 1087-1088.

11. The University and Small Business Patent Procedures Act: Hearings on S. 414 Before the S. Comm. on the Judiciary, 96th Cong. 2 (1979) [hereinafter 1979 S. Comm. on the Judiciary Hearings] (statement of Sen. Birch Bayh). 
problem. They believed that allowing the inventor to patent the invention and then license the intellectual property would provide the proper economic incentive to both inventor and licensee, leading to the full commercial development of the invention. ${ }^{12}$ Drafters of the Bayh-Dole Act were also under the impression that the Act would spur innovation in private industry because firms would no longer be afraid to accept federal funding for research on account of the invention being deemed public domain, and thus unprofitable to investors. $^{13}$

Following the enactment, universities began patenting their inventions developed under federal funding instead of placing them in public domain. ${ }^{14}$ Today, many universities assume the costs of the patent application with the hope that the patented invention will eventually garner enough interest from a private firm that the firm will want to acquire a license to the intellectual property rights. ${ }^{15}$ Universities are then able to enter into a license agreement with the private firm and generate license revenue and possible royalties for the university if the invention becomes commercially successful.

1. Is this premise correct?

Although the necessity argument for the Bayh-Dole Act was based on the premise that new incentives were needed to spur. development of federally-funded inventions, the historical record calls into question the accuracy of that premise. Research about academic institution-industry relationships regarding innovation in the first half of the $20^{\text {th }}$ Century demonstrates that patent and licensing agreements between the two were gaining momentum long before $1980 .{ }^{16}$ Initially, universities were reluctant to patent inventions that arose out of academic and faculty research because universities worried that failure to place the invention in the public domain would harm their reputation. ${ }^{17}$ However, following the Great Depression, many institutions began to change their stance on the subject as they became eager to find a path to increased revenue. ${ }^{18}$ During the 1930 s

12. Whalen, supra note 2 , at 1088.

13. Id.

14. Ritchie de Larena, supra note 3, at 1381-1382.

15. Id.

16. See David Mowery \& Bhaven Sampat, University Patents and Patent Policy Debates in the USA, 1925-1980, 10 INDUS. \& CORP. CHANGE 781 (2001).

17. Id. at 782,785 .

18. Id. at 787 . 
alone, over a dozen prominent research universities developed patent portfolios and policies. ${ }^{19}$

The onset of World War II saw a dramatic rise in federal funding of research and development in the United States, especially in the biomedical field. ${ }^{20}$ Previous to the war, funding was provided by state level sources, industry, or the Department of Agriculture. ${ }^{21}$ Federally-funded research and development resulted in increased patenting by universities, particularly in the 1970s. Universities and industry alike began to view biomedical patents as a lucrative investment opportunity, and the substantial rise in intellectual property licensing agreements between the two in the 1970 s reflected that perspective. ${ }^{22}$

Supporters of the Bayh-Dole Act, arguing that more economic incentives were needed to bring inventions to market, pointed to the small amount of the government's patent portfolio-only five-percent by the late $1970 \mathrm{~s}$ - that was licensed and fully commercialized. However, the majority of the patents held by the government at that time had been developed under federal defense contracts where the private contractors had declined to pursue title rights. ${ }^{23}$ Thus, the low number of government patents holding licensing agreements was a result of private contractors concluding that such inventions usually were not directed for civilian use or appropriate for commercialization. $^{24}$

\section{B. Terms of the Act}

As aforementioned, the Bayh-Dole Act added certain safeguards to protect against the misuse of federally funded patented inventions. Section 200 makes clear that one of the objectives of the Bayh-Dole

19. Id. at 789 (referring to Illinois, Michigan, Minnesota, Wisconsin, California, Columbia, Harvard, Pennsylvania, MIT, Cornell, Johns Hopkins, Princeton, Yale, Stanford, Chicago, and California Institute of Technology).

20. Id. at 793 ("[F]ederal funds for basic research in US universities increased sevenfold during the 1958-1968 period. The greatest increased in funding in the late 1950s and 1960s were in the biomedical sciences, funded largely by the Department of Health and Human Services, which housed the National Institutes of Health.").

21. Id. at 789

22. Id. at 793-794.

23. Id. at 797 ("Advocates of patents on university research overlooked the fact that title to most of these patents, which resulted from federal defense contracts, had been ceded to the federal government by private contractors who had not invoked their rights to retain title to the patents").

24. Id. 
Act is "to ensure that the Government obtains sufficient rights in federally supported inventions to meet the needs of the Government and protect the public against nonuse or unreasonable use of inventions; and to minimize the costs of administering policies in this area." ${ }^{25}$ These statutory rights are march-in rights and royalty free licenses.

\section{March-In Rights}

Section 203 of the Bayh-Dole Act addresses march-in rights. It states that the federal agency that funded the invention retains the right to "require the contractor, an assignee or exclusive licensee of a subject invention to grant a nonexclusive, partially exclusive, or exclusive license in any field of use to a responsible applicant or applicants, upon terms that are reasonable under the circumstances, and if the contractor, assignee, or exclusive licensee refuses such request, to grant such a license itself." In order to use this provision, though, the federal agency must determine that one of four conditions is met that necessitates agency action. These conditions include:

(1) action is necessary because the contractor or assignee has not taken, or is not expected to take within a reasonable time, effective steps to achieve practical application of the subject invention in such field of use;

(2) action is necessary to alleviate health or safety needs which are not reasonably satisfied by the contractor, assignee, or their licensees;

(3) action is necessary to meet requirements for public use specified by Federal regulations and such requirements are not reasonably satisfied by the contractor, assignee, or licensees; or

(4) action is necessary because the agreement required by section 204 has not been obtained or waived or because a licensee of the exclusive right to use or sell any subject invention in the United states is in breach of its agreement obtained pursuant to section $204 .^{26}$ 
To give the funding agency more guidance, the Bayh-Dole Act defines practical application, a term used within the first condition, as

[T]o manufacture in the case of a composition or product, to practice in the case of a process or method, or to operate in the case of a machine or system; and, in each case, under such conditions as to establish that the invention is being utilized and that its benefits are to the extent permitted by law or Government regulations available to the public on reasonable terms. ${ }^{27}$

In effect, march-in rights allow the federal agency that funded the invention to march-in on the organization that holds the patent title and issue a license to the patent to another organization. ${ }^{28}$ The new patent license holder would be able to make use of the intellectual property rights without fear of patent infringement, but would be required to make royalty payments to the patent holder. ${ }^{29}$

\section{Royalty-Free Licenses}

The Bayh-Dole Act offers another protection to the public against the unreasonable use of federally-funded patents in the form of royalty-free licenses. These licensing rights are also retained by the federal government and are identified in Section 202(c)(4) of the Act. Specifically, this provision grants the funding agency a "nonexclusive, nontransferable, irrevocable, paid up license to practice or have practiced for or on behalf of the United States any subject invention throughout the world." 30 Thus, any organization that elects to take title to and patent an invention that was researched and developed under federal funding acknowledges that the federal government retains this right in the invention.

Unlike march-in rights, the agency is not required to first make a determination that any circumstances are met before it is allowed to exercise its licensing rights under this section. ${ }^{31}$ Agencies also are not

27. 35 U.S.C.A. \& 201(f) (West 2000).

28. Thomas, supra note 7 , at 7 .

29. Id. at $7-8$.

30. 35 U.S.C.A. $\S 202(c)(4)$ (West 2000).

31. James Love, Differences Between the March-in, Royalty Free Right, and Government Use Options, KNOWLEDGE ECOLOGY INT'L (September 22, 2016, 2:50 PM), http://www.keionline.org/node/2633. 
required to make royalty payments to the patent holder should they decide to use their rights.

\section{Other Federal Licensing Rights}

There is also an additional, alternative route that the government can take when dealing with patent-protected inventions in the United States. It is not found within the Bayh-Dole Act, and therefore federal funding of the invention is not a prerequisite to government rights. 28 U.S.C. $\S 1498$ (a) provides for use of a United States patented invention by the federal government or an authorized government contractor. In order to exercise this statutory right, the patent must be "used or manufactured by or for the United States." 32 Commentators have compared this licensing right to the government's ability to exercise eminent domain when real property is needed for the common good. ${ }^{33}$ If the federal government decided to go this route, the patent holder's only remedy would be to file suit against the United States seeking damages for the government's use of the patent. $^{34}$

\section{Pricing, Health NeEds, and March-In Under BayH-Dole}

As noted above, the Bayh-Dole Act both acknowledges concerns about public access to federally-funded inventions and includes legal mechanisms for ensuring that access. In furtherance of the Act's objective to "protect the public against... unreasonable use of inventions," 35 the government is empowered to "march in" and grant a license to another manufacturer if the license holder has not made "practical application" of the invention. ${ }^{36}$

Practical application is defined as making the invention "available to the public on reasonable terms." 37 March-in rights can

32. Id.

33. See Amy Kapczynski \& Aaron Kesselheim, Government Patent Use: A Legal Approach to Reducing Drug Spending, 35 HEALTH AFF. 791, 793 (2016); see also Zain Rizvi et al., Opinion, A Simple Way for the Government to Curb Inflated Drug Prices, WASH. POST (May 12, 2016), https://www.washingtonpost.com/opinions/a-simple-way-for-the-government -to-curb-inflated-drug-prices/2016/05/12/ed89c9b4-16fc-11 e6-aa55-670cabef46e0_story.html? utm_term $=. \mathrm{d} 956 \mathrm{~d} 107 \mathrm{de} 9 \mathrm{~b}$.

34. Thomas, supra note 7 , at 8 .

35. 35 U.S.C.A. $\$ 200$ (West 2000).

36. 35 U.S.C.A. $\$ 203(1)$ (West 2000).

37. 35 U.S.C.A. $\S 201$ (f) (West 2000). 
also be asserted when the "action is necessary to alleviate health or safety needs which are not reasonably satisfied" by the license holder. $^{38}$

It does not take sophisticated legal analysis to decipher the plain meaning of phrases like "reasonable terms" and "health and safety needs." It is well-settled law that words in statutes should be interpreted in line with their ordinary meaning. ${ }^{39}$ Yet, decades of determined advocacy by holders of licenses on federally-funded inventions, in particular holders of medicine patents, has led to relevant federal agencies not even once exercising the rights granted to them by Congress. ${ }^{40}$ So, even though the meaning of the terms is plain to see, it is important to review the reasons why the unaffordable pricing of medicines and the resulting health crisis provide the foundation for the exercise of long-dormant Bayh-Dole march-in rights.

\section{A. Legislative Intent on March-In Authority and Reasonable Price}

In 2001, Professors Peter Arno and Michael Davis provided the definitive explanation for how and why the Bayh-Dole Act's marchin rights are clearly triggered by the license holder failing to make the federally-funded invention available to the public at a reasonable price:

[M]arch-in rights were preserved, with their requirement that practical application defined as availability to the public on "reasonable terms" be achieved. There was never any doubt that this meant the control of profits, prices, and competitive conditions. There are countless references in the legislative record to the need to maintain competitive market conditions through the exercise of march-in rights. ${ }^{41}$

38. 35 U.S.C.A. $\S 203(2)$ (West 2000).

39. "Statutory construction must begin with the language employed by Congress and the assumption that the ordinary meaning of that language accurately expresses the legislative purpose." Gross v. FBL Fin. Servs., Inc., 557 U.S. 167, 175-76 (2009) (quoting Engine Mfrs. Assn. v. South Coast Air Quality Management Dist., 541 U.S. 246, 252 (2004)).

40. See infra Section IV (this Article's discussion of refusal of NIH to exercise march-in and pharma influence on agency).

41. Peter S. Arno \& Michael H. Davis, Why Don't We Enforce Existing Drug Price 
As Professors Arno and Davis state, there is indeed an abundance of evidence that the Bayh-Dole Act's march-in provisions were devised to ensure that federally-funded inventions be available to the public at reasonable prices. An analysis of that evidence should begin with the recognition that the legislation, as proposed, represented a significant shift in government practice. Federal government investment in research during World War II, and beyond, was subject to a clear requirement that the public interest requires that all rights to such inventions be assigned to the Government, and not left to the private ownership of the contractor. ${ }^{42}$

The change to this settled approach proposed by Bayh-Dole was jarring to many, and outright offensive to some. Senator Russell Long of Louisiana said of the bill that he saw "absolutely no reason why the taxpayer should be forced to subsidize a private monopoly and have to pay twice: first for the research and development and then through monopoly prices." ${ }^{43}$ Admiral H.G Rickover testified to Congress that the proposal was a multi-billion dollar "giveaway," a view that members of Congress acknowledged was widely held. ${ }^{44}$ Consumer advocates and anti-trust lawyers rang alarm bells. ${ }^{45} \mathrm{~A}$ Department of Justice review of the legislation emphasized the need to provide "adequate protection of the public's equitable interest in inventions that result from government funding." 46 Witnesses testifying to

Controls? The Unrecognized and Unenforced Reasonable Pricing Requirements Imposed Upon Patents Deriving in Whole or in Part from Federally Funded Research, 75 TUL. L. REV. 631,662 (2001).

42. ATt'y Gen. OF THE U.S., InVESTIGATION OF GOVERNMENT PATENT PRACTICES AND POLICIES: REPORT AND RECOMMENDATIONS OF THE ATTORNEY GENERAL TO THE PRESIDENT (1947), reprinted in SUBCOMM. ON DOMESTIC AND INT'L SCI. PLANNING AND ANALYSIS OF THE H. COMM. ON SCI. AND TECH., 94TH Cong., 2 BACKGROUND MATERIALS ON GOVERNMENT PATENT POLICY: THE OWNERSHIP OF INVENTIONS RESULTING FROM FEDERALLy Funded RESEARCH AND DEVELOPMENT: REP. OF COMM., COMM'N \& MAJOR STUDIES, at 22 (Comm. Print 1976).

43. Patent Policy. J. Hearing Before the S. Comm. on Commerce, Sci., \& Transp. \& the S. Comm. on the Judiciary, 96th Cong. 464 (1980).

44. Hearings on S. 1215 Before the Subcomm. on Sci., Tech., \& Space of the S. Comm. on Commerce, Sci., \& Transp., 96th Cong. 401 (1979); 126 CONG. REC. 29,898 (1980) (statement of Rep. Brown) ("I am aware of the concern that granting contractors exclusive rights to federally funded inventions is a 'give-away' of the taxpayers' property.").

45. Jennifer A. Henderson \& John. J. Smith, Academia, Industry, and the Bayh-Dole Act: An Implied Duty to Commercialize, CTR. FOR INTEGRATION MED. \& INNOVATIVE TECH. 3 (Oct. 2002), http://citeseerx.ist.psu.edu/viewdoc/download?doi=10.1.1.453.1958\& rep=rep1 \&type $=$ pdf.

46. Patent and Trademark Law Amendments of 1980: Hearings on H.R. 6933 Before a Subcomm. of the H. Comm. on Gov't Operations, 96th Cong. 97 (1980) (testimony of Ky P. 
Congress emphasized the need for the final version of the bill to include safeguards ensuring that federally-funded inventions would be available at a reasonable price and preserve the right of the government to intervene if the "market price is unreasonable."

Bill co-sponsor Senator Birch Bayh was well aware of these concerns, and insisted that the legislation acknowledged and addressed them:

[Bill criticism] comes from those that feel that this bill is a front to allow the large, wealthy, corporation to take advantage of Government research and thus to profit at taxpayer's expense. We thought we had drafted the bill in such a way that this was not possible. ${ }^{48}$

The provision of the bill that members of Congress believed would protect the taxpaying public was the march-in provision, with Bayh's co-sponsor Senator Robert Dole going on record to say that march-in rights were designed to "diffuse the danger of monopolies." ${ }^{49}$ A multitude of witnesses echoed the co-sponsors' statements, testifying that march-in rights were the designated protection for the public interest, particularly against monopolies' impact on market pricing. ${ }^{50}$ As U.S. Comptroller Elmer B. Staats

Ewing, Jr.).

47. Government Patent Policy: Hearings Before the Subcomm. on Domestic \& Int'] Scientific Planning \& Analysis of the H. Comm. on Sci. \& Tech., 94th Cong. 785 (1976) (supplemental materials of William O. Quesenberry).

48. 1979 S. Comm. on the Judiciary Hearings, supra note 11, at 44 (statement of Sen. Birch Bayh).

49. 126 CONG. REC. 8,739 (1980) (statement of Sen. Robert Dole).

50. See $1979 \mathrm{~S}$. Comm. on the Judiciary Hearings, supra note 11, at 44 (statement of Elmer B. Staats, U.S. Comptroller Gen.); id. at 70 (statement of Dr. Hector F. DeLuca, Chairman, Biochemistry Dept., University of Wisconsin Madison); id. at 187 (statement of Howard Bremer, President, Society of University Patent Administrators); Patent Policy: Hearings Before the Subcomm. on Sci., Tech., and Space of the S. Comm. on Commerce, Sci. and Transp., 96th Cong. 182 (1979) [hereinafter 1979 Senate Sci. Hearings] (statement of Gerald J. Mossinghoff, Deputy Gen. Counsel, NASA); id. at 366 (statement of Dale W. Church, Deputy Under Secretary of Defense for Acquisition Policy); Government Patent Policy: Hearings Before the Subcomm. on Sci, Research and Tech. of the H. Comm. on Sci. and Tech., 96th Cong. 54 (1979) [hereinafter 1979 House Sci. Hearings] (statement of John E. Maurer, Director, Patent Dept., Monsanto Corp.); id. at 182 (statement of Ralph L. Davis, Purdue Research Found.); Government Patent Policies: Hearing Before $S$. Small Business Comm., 95th Cong. 189-195 (statement of John H. Shenefield, Asst. Att'y Gen., Antitrust Div., U.S. Dept. of Justice). 
testified to the Senate, "march-in rights to protect the public's interest were developed to take care of and address the patent policy issues of contractor's windfall profits, suppression of technology, and the detrimental effects to competition from granting contractors rights to inventions." 51

In fact, march-in rights under Bayh-Dole actually represented a legislative compromise that further demonstrates the rights' clear meaning. A proposed pro-taxpayer "pay-back provision" that would have required license holders to compensate the government out of profits was rejected. ${ }^{52}$ But so was the industry's spirited opposition to march-in rights and request that the "reasonable terms" requirement be removed or neutralized. ${ }^{53}$ The final legislation's retention of march-in rights despite these repeated industry objections is significant evidence that Congress fully intended march-in rights to be what the statute's plain meaning says they are: protection for the public's access to the inventions its tax dollars paid for.

Although industry representatives argue today that pricing cannot trigger march-in rights, ${ }^{54}$ they conceded this point at the time of Bayh-Dole's passage. A former Assistant Secretary of Commerceturned-corporate representative told the Senate that march-in provisions protected not just against non-use of the invention but also against "abuse" of the monopolies that were detrimental to "the welfare of the people." "55 Henry F. Manbeck, General Patent Counsel for General Electric Company, made it even more clear, saying of march-in rights, "[I]f [a contractor] fails to supply the market adequately at a fair price, then there is reason for requiring it to

51. $1979 \mathrm{~S}$. Comm. on the Judiciary Hearings, supra note 11, at 56 (statement of Elmer B. Staats, U.S. Comptroller Gen.).

52. $1979 \mathrm{~S}$. Comm. on the Judiciary Hearings, supra note 11, at 8-10, 25-26 (1979).

53. 1979 Senate Sci. Hearings, supra note 50, at 221 (statement of Peter F. McCloskey) (industry request to make the "reasonable terms" requirement not apply if "the invention is being worked.").

54. How The BAyH-Dole ACT PROPElled U.S. Global Leadership IN LifE SCIENCES, 22-26, http://phrmacdn.connectionsmedia.com/sites/default/files/pdf/bayh-doleact-white-paper-summary.pdf (last viewed February 11, 2017).

55. David Halperin, THE BaYH-DOle ACT AND MARCh-IN Rights 6 (2001), http://www.essentialinventions.org/legal/norvir/halperinmarchin2001.pdf; see also $1979 \mathrm{~S}$. Comm. on the Judiciary Hearings, supra note 11, at 153-154 (testimony of Betsy AnckerJohnson, Vice President, Gen. Motors Environmental. Activities Staff, Former Assistant Secretary of Commerce). 
license both the background patents and the patents stemming from the contract work." 56

\section{B. Other Analyses of March-In Rights}

Since Arno's and Davis' seminal article, multiple legal and public policy experts have weighed in with their agreement that the Bayh-Dole march-in provisions clearly contemplate government licensure when the license holder takes advantage of its monopoly to set unaffordable prices on the federally-funded invention. Those analysts have concurred that unreasonable pricing violates the Act's "reasonable terms" requirement under Section 203(1) and, in instances of health-related technology such as medicines, can invoke the health and safety protections that are the subject of Section 203(2). ${ }^{57}$

Among those who have signed onto this view in the years since Bayh-Dole's passage was legislation co-sponsor former Senator Bayh. In 1997, former Senator Bayh filed a petition with the U.S. Department of Health and Human Services requesting a march-in license for Cell-Pro, Inc. to use technology discovered with federal funding and licensed to Johns Hopkins University. In that petition, former Senator Bayh argued that march-in was justified in part due to concerns about prices paid by consumers for the invention, citing "unreasonably high royalties and prices of medical care." 58

There have been arguments over the years arguing for an interpretation of march-in rights that is so narrow that it reduces pricing to irrelevancy. ${ }^{59}$ But, as one journalist recently noted, "it is also fair to say that most of the attorneys who make this argument represent drug companies." 60 Unfortunately, that group includes the

56. 1979 House Sci. Hearings, supra note 50, at 48 (emphasis added).

57. See Halperin, supra note 55; see also University Research and the Patent System: Hearing Before the S. Comm. on the Judiciary, 110th Cong. (2007) (statement of Robert Weissman, Director, Essential Action), http://www.judiciary.senate.gov/imo/media/doc/07-1024WeissmanTestimony.pdf; Thopher Sipro et al., Enough Is Enough: The Time Has Come to Address Sky-High Drug Prices, CENTER FOR AM. PROGRESS, 27-28 (September 18, 2015), https:/cdn.americanprogress.org/wp-content/uploads/2015/09/15131852/DrugPricingReformsreport1.pdf.

58. James Love, Birch Bayh's competing interests and evolving views, KNOWLEDGE ECOLOGY INT'L (August 23, 2012, 7:07 PM), http://keionline.org/node/1537.

59. John H. Rabitschek \& Norman J. Latker, Reasonable Pricing - A New Twist for March-in Rights Under the Bayh-Dole Act, 22 SANTA CLARA HIGH TECH. L.J 149 (2005).

60. Alicia Mundy, Just the Medicine: How the next president can lower drug prices with the stroke of a pen, WASH. MONTHLY (November/December 2016), http://washingtonmonthly 
bill's two co-sponsors, in their post-Senate iterations as industry lobbyists, with Bayh directly reversing course from his 1997 position. While working either directly for pharmaceutical companies (Dole) or a law firm representing pharmaceutical companies (Dole and Bayh), they wrote a 2002 letter to the editor of the Washington Post claiming that they never intended pricing to be a factor that could invoke march-in rights. ${ }^{61}$

Financial inducements aside, it is difficult to sustain a straightfaced argument that "reasonable terms" does not include the price charged for the invention. As University of Michigan law professor Nicholas Bagley put it in 2015, echoing the generations of jurisprudence on statutory interpretation:

[It is] a powerful and straightforward argument that the federal government could conclude that a drug is "not available on reasonable terms" if its price is exorbitant. In contract negotiations, price is a term. Indeed, it is often the most important term. Why would you read a statute written like that to exclude any consideration of prices? ${ }^{62}$

As Professor Bagley and others have noted, the terms of the law are plain enough in isolation. But, taken as a whole, they even more clearly call for the consideration of price of the monopoly-protected invention. The arguments made against "reasonable terms", including price, hold that the only Bayh-Dole requirement of a license holder is to make the invention commercially available. ${ }^{63}$ Unfortunately, that interpretation seems to also form the basis of several National Institutes of Health decisions rejecting march-in petitions, more fully described in Section IV.

That interpretation violates a rule of statutory construction as well-settled as the ordinary meaning rule: all words of a statute should be considered to have a purpose, and should be given effect. ${ }^{64}$ If

.com/magazine/novemberdecember-2016/just-the-medicine/.

61. Birch Bayh \& Bob Dole, Our Law Helps Patients Get New Drugs Sooner, WASH. PosT (April 11, 2002).

62. Nicholas Bagley, Pushing back on exorbitant drug prices, INCIDENTAL ECONOMIST (September 21, 2015, 10:00 AM), http://theincidentaleconomist.com/wordpress/pushing-backon-exorbitant-drug-prices/.

63. Rabitschek \& Latker, supra note 59 , at 160.

64. Gross v. FBL Fin. Servs., Inc., 557 U.S. 167, 175-76 (2009). Beyond simply 
Congress had intended the only obligation of the license holder to be making the invention commercially available, it would have concluded its definition of "practical application" with the requirement contained there that the invention be "available to the public." ${ }^{65}$ But Congress did not stop there. It added to the definition the mandate that the invention not just be available but must be so "on reasonable terms." ${ }^{\prime 66}$ Clearly, mere commercialization of the invention is not sufficient to meet a license holder's obligations.

\section{Health and Safety Needs and March-In}

Most of the scholarly and policy debates about Bayh-Dole march-in have focused on the pricing component of the "reasonable terms" requirement under Sections 201(f) and 203(1). But, the medicines pricing and access crisis outlined in Section VI of this Article just as clearly call for march-in to be exercised under the "health and safety needs" justification included in Section 203(2). In fact, even scholars who argue that "reasonable terms" does not include pricing concede that high medicine prices could justify a health-related march-in. ${ }^{67}$

During the Bayh-Dole hearings, one expert intellectual property and government attorney specifically referenced cancer treatment in this context:

Whenever you discuss patent policy, you very quickly come up with the question of what do you do with a cure for cancer? Are you going to let one company have that? Obviously, a priceless invention... The Government might need to acquire title, because that would be an exceptional circumstance. ${ }^{68}$

ignoring the phrase "reasonable terms," it is similarly impossible to coherently argue that "reasonable terms" does not include consideration of pricing, given the abundant case and regulatory law. See Arno \& Davis, supra note 41, at 650-652, and legislative history, supra notes $48-57$, showing it does.

65. 35 U.S.C.A. $\S 201(f)$ (West 2000).

66. Id.

67. Rabitschek \& Latker, supra note 59, at 167.

68. Patent Policy: Hearings Before the Subcomm. on Sci, Tech, and Space of the Comm. on Commerce, Sci. and Transp., 96th Cong. 44 (1979) (statement of R. Tenney Johnson). 
As is more fully discussed in Section VI, the scenario imagined in the late $1970 \mathrm{~s}$ is reality today. Recent decades have seen historic breakthroughs in cancer treatment in particular, thanks in significant part to federal funding that led to these inventions. ${ }^{69}$ Yet, those medicines are not available to all, including U.S. taxpayers. The cost of cancer medicine in the U.S. exceeds $\$ 100,000$ per patient per year, and U.S. oncologists report that one in five of their patients do not fill prescriptions due to cost. ${ }^{70}$ The current situation, as illustrated by the Xtandi pricing and access crisis described in Section VI, is a perfect match for the scenario anticipated by the "health and safety needs" march-in option.

When faced with similar significant needs in the past, the U.S. government has not hesitated to take, or at least threaten to take, compulsory licensing such as that enabled by the Bayh-Dole march-in provisions. The most high-profile example occurred in 2001, when the U.S. was confronted with the purposeful spread of the deadly infectious disease anthrax. Envelopes containing anthrax spores, postmarked September 18, 2001, were mailed to major U.S.-based media outlets. Two more infected envelopes, these post-marked October 9, 2011, were mailed to two U.S. Senators. Twenty-two people were infected with anthrax due to the mailings, and five died. ${ }^{71}$ The only approved oral treatment for anthrax was the antibiotic ciprofloxacin, patented and marketed in the U.S. by Bayer Corporation under the name Cipro. This appeared to present a problem: there was a limited supply of Cipro in the U.S., and the price was thirty times higher than in nations where generic versions were available. $^{72}$

The response by the U.S. government was swift. Tommy Thompson, the Secretary of the U.S. Department of Health and Human Services, demanded that Bayer significantly discount the price of Cipro. If Bayer failed to do so, Thompson vowed to seek

69. Enhancing Drug Discovery and Development, NAT'L CANCER INST. (Sept. 11, 2015), https://www.cancer.gov/research/areas/treatment/enhancing-drug-discovery.

70. Ayalew Tefferi et al., In Support of a Patient-Driven Initiative and Petition to Lower the High Cost of Cancer Drugs, 90 MAYO CLINIC PROC. 966, 997 (2015), http://www.mayo clinicproceedings.org/article/S0025-6196(15)00430-9/pdf.

71. Timeline: How the Anthrax Terror Unfolded, NAT'L PuB. Radio (Feb. 15, 2011), http://www.npr.org/2011/02/15/93170200/timeline-how-the-anthrax-terror-unfolded.

72. Keith Bradsher, The Antibiotic; Bayer Insists Cipro Supply is Sufficient; Fights Generic, N.Y. TIMES (Oct. 21, 2001), http:/www.nytimes.com/2001/10/21/us/nationchallenged-antibiotic-bayer-insists-cipro-supply-sufficient-fights.html. 
Congressional approval to obtain a generic version of the medicine. "The price is the question, not the supply," Thompson told a Congressional committee in October 2001. ${ }^{73}$ After Thompson's testimony, the chair of that committee publicly stated that any request to bypass the Bayer patent would likely be approved by Congress. ${ }^{74}$ That proved unnecessary. Bayer got the message and responded by cutting its Cipro price in half and pledging to provide 100 million tablets. $^{75}$

This was not the first or last time the U.S. government responded to a health crisis with threats of compulsory licensing to a different manufacturer. In 1994, the U.S. responded to concerns over the price of the HIV/AIDS drug AZT by requiring companies to sign terms committing to "reasonable pricing." " In the late 1950s and early 1960 s, the U.S. military repeatedly ignored Pfizer's U.S. patent for the antibiotic tetracycline. Instead, the military simply ordered a generic version for less than half the price from a manufacturer in Italy, where medicine patents were not enforced. ${ }^{77}$

In 2004, the U.S. government threatened Abbott Laboratories with an override of its patent for the HIV/AIDS drug ritonavir. Like Bayer did with the Cipro threat, Abbott got the message and dropped its price $80 \%$ for patients in federally-funded programs. ${ }^{78}$ Anti-trust litigation and/or threats of a government patent override has led to compulsory licenses being issued for stem cells, laser eye surgery, gene therapy, ultrasound imaging catheters, and the irritable bowel

73. Associated Press, Government Threatens to Suspend Patent on Cipro, USA TODAY (Oct. 23, 2001), http://usatoday30.usatoday.com/news/attack/2001/10/23/anthrax-cipro.htm.

74. Keith Bradsher \& Edmund L. Andrews, A Nation Challenged: Cipro; U.S. Says Bayer Will Cut Cost of Its Anthrax Drug, N.Y. TIMES (Oct. 24, 2001), http://www.nytimes $. c o m / 2001 / 10 / 24 /$ business/a-nation-challenged-cipro-us-says-bayer-will-cut-cost-of-itsanthrax-drug.html.

75. Id.

76. NAT'L INST. OF HEALTH, REPORTS OF THE NIH PANELS ON COOPERATIVE RESEARCH AND DEVELOPMENT AGREEMENTS: PERSPECTIVES, OUTLOOK, AND POLICY DEVELOPMENT: JULY 21, 1994 AND SEPTEMBER 8, 1994 (1994); In fact, until 1995, a reasonable pricing clause was a boilerplate provision in all of its cooperative research and development agreements (Rabitschek \& Latker, supra note 59, at 166-167).

77. Ellen F.M. 'T Hoen, The Global Politics of Pharmaceutical Monopoly POWER: DRUG PATENTS, ACCESS, INNOVATION AND THE APPLICATION OF THE WTO DOHA DECLARATION ON TRIPS AND PUBLIC HEALTH 43 (2009), http://apps.who.int/medicinedocs /documents/s20963en/s20963en.pdf.

78. James Love, KEIResearch Note: Recent United States Compulsory Licenses, KNOWLEDGE ECOLOGY INT'L 6 (Mar. 7, 2014), http://keionline.org/sites/default/files/Annex_. A_US_Compulsory_Licenses_7Mar2014_8_5x11.pdf [hereinafter Recent U.S. Compulsory Licenses]. 
syndrome drug dicyclomine. ${ }^{79}$ In a single five-year period from 2006 to 2011, U.S. courts issued six different compulsory licenses for medical technologies. ${ }^{80}$

The U.S. President's Emergency Plan for AIDS Relief, PEPFAR, is reported to be the world's leading consumer of generic medicines manufactured under compulsory licenses. ${ }^{81}$ In 2010 , the Affordable Care Act included a mechanism for compulsory licenses to ensure U.S. access to patented biologic drugs. ${ }^{82}$ The U.S. government has even exercised rights analogous to the Bayh-Dole march-in rights in multiple non-health-related contexts, when a determination was made that the public interest called for it. The U.S. has issued multiple compulsory licenses for patents to military technologies like satellites, camouflage screens, and protective eyewear. $^{83}$

The U.S. has also issued compulsory licenses for advances in energy technology and methods to reduce air pollution. ${ }^{84}$ Often, compulsory licenses have been the remedy of choice in resolving U.S. anti-trust lawsuits, including the blunting of patents for the manufacture of truck parts, plastics, personal computers, corn seeds, microprocessors, animal vaccines, and gasoline. ${ }^{85}$

As described in Sections V and VII, a health crisis exists, federally-funded inventions exist to address it, but those inventions are priced beyond any reasonable level. Clearly, the time has come for "action... necessary to alleviate health and safety needs which are not reasonably satisfied." $" 86$

79. James Love \& Michael Palmedo, Examples of Compulsory Licensing of Intellectual Property in the United States. Chapter 2, CPTECH BACKGROUND PAPER 1 (Sept. 29, 2001), $\mathrm{http}: / /$ www.cptech.org/ip/health/cl/us-1498.html.

80. James Love, Open Letter to Those Who Collectively Produced the May 23, 2012 Statement to the WIPO SCP on the Topics of Patents and Health, KNOWLEDGE ECOLOGY INT'L (May 25, 2012) http://keionline.org/node/1420.

81. James Love, Open Letter to Patent Office, on Its War Against the Global Poor, HUFFINGTON POST (May 25, 2012) http://www.huffingtonpost.com/james-love/open-letter-topatentoff_b_1545232.html.

82. Recent United States Compulsory Licenses, supra note 78, at 10.

83. James Love \& Michael Palmedo, Examples of Compulsory Licensing of Intellectual Property in the United States, CPTECH BACKGROUND PAPER 1 (Sept. 29, 2001), http://www.cptech.org/ip/health/cl/us-cl.html.

84. Id.

85. Id. and Recent U.S. Compulsory Licenses, supra note 78, at 1-2.

86. 35 U.S.C.A. $\$ 203$ (1)(b) (West 2000). 


\section{THE IMPACT OF BAYH-DOLE ON THE AVAILABILITY OF FEDERALLY-FUNDED INVENTIONS}

As stated in Section II, the Bayh-Dole Act enabled universities to acquire patents on the fruits of federally funded research, a change in approach aimed at spurring innovation and increasing access to those inventions. ${ }^{87}$ In the field of biomedicine, it is worthwhile to consider the Act's impact on innovation, access, and the research institutions involved.

\section{A. Has Bayh-Dole Spurred Innovation in Medicines?}

Since the Act's passage, there have been many published positive reviews issued by observers, enthusiastically asserting that the legislation has achieved its purpose. Many of those pronouncements quote the particularly fervent praise by The Economist in 2002 that Bayh-Dole is "[p]ossibly the most inspired piece of legislation to be enacted in America over the past halfcentury." 88

At first glance, that claim seems to be supported by the sheer number of patents awarded to universities in the wake of the Act's passage. In the twenty years after Bayh-Dole, universities produced ten times as many patents as they did in the similar period before the Act, and created thousands of new companies designed to commercialize those discoveries. ${ }^{89}$ Human biology patents increased $300 \%$ in the first five years after the Act became law. ${ }^{90}$ Citing such data, along with The Economist's 2002 commendation, one intellectual property attorney has written that "Bayh-Dole is objectively positive" and any assertion to the contrary is "complete and utter nonsense." "91 Others have hailed the Act's "unquestioned success." 92

87. 35 U.S.C.A. $\S 200$ (West 2000 ).

88. Innovation's Golden Goose, THE ECONOMIST, Dec. 14, 2002, at 3.

89. Aaron S. Kesselheim, An Empirical Review of Major Legislation Affecting Drug Development: Past Experiences, Effects, and Unintended Consequences, 89 MILBANK Q. 450 (Sept. 2011), https://www.ncbi.nlm.nih.gov/pmc/articles/PMC3214718/.

90. Peter Drahos \& John Braithwaite, Who Owns The Knowledge Economy: Political Organising Behind TRIPS, CORNER HOUSE BRIEFING 32 (Sept. 30, 2004), http://www. thecornerhouse.org.uk/sites/thecornerhouse.org.uk/files/32trips.pdf.

91. Gene Quinn, Intellectual Dishonesty About Bayh-Dole Consequences, IP WATCHDOG (May 10, 2013), http://www.ipwatchdog.com/2013/05/10/intellectual-dishonesty 
Yet, there are significant questions about whether Bayh-Dole has been successful in achieving its stated aims. For example, a team of global health and intellectual property scholars wrote in 2008 that the claims surrounding the economic impact of the Act are "overstated and misleading." $" 93$ They and others have argued that the sharp increase in post-legislation academic research patent activity reflects in part increased federal funding of that research, and that some of the patented post-Bayh-Dole discoveries could have been commercialized without the exclusive licenses of patents. ${ }^{94}$

Most importantly, these scholars and others note that a spike in the number of patents does not necessarily signal either true innovation or benefits received by patients and taxpayers, especially given the well-established legacy in the biomedical field of superfluous "patent thickets" and the patenting of non-innovative "me too" drugs. ${ }^{95}$ In fact, one analysis of pharmacological advances in the decades before and after Bayh-Dole showed less clinically-improved new drugs being offered after the Act's passage than in the years leading up to the legislation. ${ }^{96}$

\section{B. Has Bayh-Dole Improved Access to Federally-Funded Inventions?}

As is more fully discussed in Section III above, the debates surrounding the consideration of the Bayh-Dole legislation featured significant concerns that private licensing of federally-funded inventions may have a negative impact on those inventions being

-about-bayh-dole-consequences $/ \mathrm{id}=40200 \%$.

92. Rabitschek \& Latker, supra note 59, at 150.

93. Anthony D. So et al., Is Bayh-Dole Good for Developing Countries? Lessons from the US Experience, 6 PLOS BIOLOGY 2078, 2082 (Oct. 2008), http://journals.plos.org /plosbiology/article?id=10.1371/journal.pbio.0060262.

94. DAVID C. MOWERY ET AL., IVORY TOWER AND INDUSTRIAL INNOVATION: UNIVERSITY-INDUSTRY TRANSFER BEFORE AND AFTER BAYH-DOLE (2004); see also Michele Boldrin et al., Competition and Innovation, 1 Cato Papers on Public Pol'y 109 (2011) (demonstrating that the increase in patents does not necessarily mean more innovation); Gerald Barnett, University IP Bustle and Evidence for Bayh-Dole's Performance, RES. ENTERPRISE (Feb. 3, 2017), http://researchenterprise.org/2017/02/03/university-ip-bustle-and-evidence-forbayh-doles-performance/ (arguing that actual university commercialization rates are low and describing the inefficiencies created in the patent system under the Bayh-Dole Act).

95. Els Torreele, Only a Radical Overhaul Can Reclaim Medicines for the Public Interest, PLOS: BLOGS (Oct. 13, 2015), http://blogs.plos.org/yoursay/2015/10/13/talkingabout-drug-prices-access-to-medicines/.

96. Donald W. Light \& antonio F. Maturo, good Pharma: The Public-Health MODEL OF THE MARIO NEGRI INSTITUTE 197 (2015). 
available to the taxpayers who supported their creation. ${ }^{97}$ Economist Walter Valdivia has explained how, for Bayh-Dole to be considered successful, it must result in the fruits of federally-funded medicines research being affordable:

That a public patent is developed into a product doesn't directly imply maximum social benefit. If a new product is priced so high that only very few people can afford it, the social return will be minimal. Consider the effect of innovation in the pricing of drugs ... [A] good indicator of the social return on public investment in biomedical research is therefore affordability. ${ }^{98}$

Affordability is an enormous concern with patented medicines generally, with monopoly-protected medicines routinely being priced at levels hundreds of times higher than generic alternatives. ${ }^{99}$ Patent monopolies shield drug-makers from market forces, as demonstrated by pharmaceutical corporations raising their product prices by $12 \%$ annually in recent years, far above the rate of inflation. ${ }^{100}$ Despite an outsized national role in funding medicine innovation, U.S. patients pay the highest prices in the world for prescription drugs. ${ }^{101}$ More than one in four Americans report cost being a cause for not filling a prescription written by their physician. ${ }^{102}$

97. $1979 \mathrm{~S}$. Comm. on the Judiciary Hearings, supra note 11, at 157 (statement of Admiral Hyman Rickover) ("[i]n my opinion, Government contractors-including small businesses and universities-should not be given title to inventions developed at Government expense .... These inventions are paid for by the public and therefore should be available for any citizen to use or not as he sees fit.").

98. Walter Valdivia, Tech Transfer Policy: Bayh-Dole has Distributional Consequences, II INNOVATION(Apr.-May 2013).

99. Generic Competition and Drug Prices, U.S. FoOd \& Drug AdMIN. (May 13, 2015), http://www.fda.gov/AboutFDA/CentersOffices/OfficeofMedicalProductsandTobacco/CDER/u cm 129385.htm.

100. Medicines Use and Spending in the U.S.-A Review of 2015 and Outlook to 2020, QUINTILESIMS (Apr, 2016), http://www.imshealth.com/en/thought-leadership/quintilesimsinstitute/reports/medicines-use-and-spending-in-the-us-a-review-of-2015-and-outlook-to-2020.

101. German Lopez, After Public Outcry, Pharmaceutical Company to Cut Price of Drug It Hiked by 5,500 Percent, Vox (Sept. 22, 2015, 7:16 PM), http://www.vox.com/2015 /9/22/9375295/turing-daraprim-price-cut.

102. Gabrial Levitt, 50 Million Americans, Ages 19-64, Forgo Meds in 2012 Due to Cost; 37\% of Seniors Concerned About Drug Prices, PharmacyChECKer Blog (May 10, 2013), https:/www.pharmacycheckerblog.com/50-million-americans-ages-19-64-forgo-medsin-2012-due-to-cost; Bianca DiJulio et al., Kaiser Health Tracking Poll: August 2015, KAISER 
Remarkably, this pricing pattern holds true even for medicines discovered with federal funding. A 2011 study of medicines for diseases that include cancer, heart disease, and diabetes showed that medicines whose discovery was federally-funded were priced higher in the U.S. than in other, comparably high-income, countriescertainly not an outcome in line with the stated Bayh-Dole legislative intent of improving access to those discoveries. ${ }^{103}$

Often, as is the case with the drug Xtandi discussed in Section V, those high medicine prices are being paid in significant part by the U.S. government. Government programs like Medicare ( $\$ 162$ billion in 2015) ${ }^{104}$ and Medicaid ( $\$ 57.3$ billion in 2015) $)^{105}$ incur enormous drug purchasing costs, even while the National Institutes of Health $\left(\$ 32\right.$ billion per year) ${ }^{106}$ and other federal agencies are the unquestioned premier funders of early-stage medicine research.

Perhaps the most high-profile example of this phenomenon is the case of Hepatitis $\mathrm{C}$ medicines based on sofosbuvir, developed at an academic institution with federal funding. ${ }^{107}$ The medicine's patent is now held by Gilead Sciences, and its resulting price tag of as much as $\$ 84,000$ for a single patient is causing enormous financial pressure for federal and state health agencies forced to pay the monopoly mark-up for a drug that can be manufactured for as little as $\$ 68$, and is sold in other countries for as little as $\$ 300 .^{108}$ As one analyst has said, when it comes to medicines, governments plays the role of "incompetent venture capitalists," paying at both the front and back ends of the process. ${ }^{109}$

FAMILY FOUND. (Aug. 20, 2015), http://kff.org/health-costs/poll-finding/kaiser-healthtracking-poll-august-2015/.

103. Tedmund Wan, 2011: Survey of Drug Prices for 14 Drugs with US Government Rights in Patents Listed in the FDA Orange Book, KNOWLEDGE ECOLOGY INT'L (Nov. 11, 2011), http://www.keionline.org/node/1541.

104. Update to Medicare Drug Spending Dashboard, CTRS. FOR MEDICARE \& MEDICAID SRVS. (Nov. 14, 2016), https://www.cms.gov/Newsroom/MediaReleaseDatabase /Fact-sheets/2016-Fact-sheets-items/2016-11-14.html.

105. Id.

106. Budget, NAT'L INSTS. OF HEALTH (Apr. 4, 2016), https://www.nih.gov/aboutnih/what-we-do/budget.

107. Veronika J. Wirtz et al., Essential Medicines for Universal Health Coverage, 389 LANCET 403, 408 (Nov. 7, 2016), http://www.thelancet.com/pdfs/journals/lancet/PIIS01406736(16)31599-9.pdf.

108. Id.

109. Fran Quigley, Patients Before Profits, COMMONWEAL (June 28, 2016), https://www.commonwealmagazine.org/patients-profits. 
For the most valuable medicines, the U.S. government plays an even more crucial role. With pharmaceutical corporations' research inevitably focused on the search for profitable products, that research often prioritizes non-critical health needs such as cosmetic or sexual performance drugs or "me too" drugs, the non-innovative medicines aimed at carving out a piece of an existing lucrative market. ${ }^{110}$ That leads the NIH and other government funders to take the leadership role in discovering the most impactful medicines. A study of drugs receiving the priority review status from the US Food and Drug Administration, meaning that the medicines would provide a significant improvement in treatment, showed that two-thirds of them traced their roots back to government-funded research. ${ }^{111}$

Ironically, even fervent supporters of Bayh-Dole cannot avoid underscoring the medicines' accessibility problem, even when making the case for the Act's positive impact. The same intellectual property attorney who wrote that Bayh-Dole's record is "objectively positive" (and accused those who expressed concerns about the Act of intellectual dishonesty) referenced in the same article medicines like the leukemia drug Gleevec and the breast cancer drug Herceptin. ${ }^{12} \mathrm{~A}$ testimonial highlighted in the article acknowledged that the basic research that led to medicines like these was funded by the federal government because that research "is generally too risky and too expensive for private industry to undertake alone." 113

Yet, the very drugs referenced are some of those most widely condemned as examples of breathtaking cost inflation far beyond either private manufacturing cost or private research investments, leading to enormous corporate profit margins and corresponding patient accessibility problems. ${ }^{114}$ The corporation Novartis makes $\$ 4.7$ billion per year from government-discovered Gleevec, which is

110. Torreele, supra note 95.

111. Bhaven N. Sampat \& Frank R. Lichtenberg, What Are The Respective Roles Of The Public And Private Sector In Pharmaceutical Innovation?, 30 HeAlTH AFF. 332 (Feb. 2011), http://www.healthaffairs.org/doi/pdf/10.1377/hlthaff.2009.0917.

112. Quinn, supra note 91.

113. Id.

114. Carolyn Y. Johnson, This Drug is Defying a Rare Form of Leukemia - and It Keeps Getting Pricier, WASH. POST (Mar. 9, 2016), https://www.washingtonpost.com/business/thisdrug-is-defying-a-rare-form-of-leukemia - and-it-keeps-getting-pricier/2016/03/09/4fff8102c571-11 e5-a4aa-f25866ba0dc6_story.html; Treatment Action Campaign, People Living with Cancer Join the Fix the Patent Laws Campaign, INFOJUSTICE.ORG (Feb. 5, 2015), http://infojustice.org/archives/33877. 
priced as high as $\$ 120,000$ per year for a single patient. ${ }^{15}$ One analysis estimated that it only takes Novartis thirteen days of Gleevec sales revenue to cover the corporation's research and development investment. ${ }^{116}$ Herceptin's manufacturer, Roche, made $\$ 11.6$ billion in profits in 2015 from the medicine discovered in significant part due to federal funding, and charges as much as $\$ 70,000$ for a year's dose. ${ }^{117}$ These are two of many medicines in this category.

Another widely quoted Bayh-Dole supporter is former Yale president Richard Levin, who in 2001 memorably praised the Act as a "benefit to humanity." 118 That very same year, Yale was the target of intense global criticism for its allegedly inhumane handling of federally-funded medicine research on its campus. ${ }^{119}$ It turns out that stavudine, a key drug to address HIV/AIDS, had been discovered at Yale with federal funding, and then licensed to a pharmaceutical corporation that was paying Yale $\$ 40$ million per year in fees. ${ }^{120}$ Those fees were enabled by the corporation pricing the drug hundreds of times higher than its manufacturing cost. ${ }^{12}$

That price was far beyond the means of millions of people dying untreated of HIV/AIDS each year, particularly in sub-Saharan Africa. ${ }^{122}$ Among the critics of the price barrier and resulting inaccessibility was the Yale professor who invented the drug. ${ }^{123}$ Activist pressure eventually forced Yale and its co-licensee to lower its price, but the millions of HIV/AIDS patients who died untreated

115. Johnson, supra note 114.

116. James Love, R\&D Costs for Gleevec, KNOWLEDGE ECOLOGY INT'L (Apr. 3, 2013, 8:07AM) http://keionline.org/node/1697.

117. John Miller, Roche Annual Profit Disappoints, Outlook Muted, REUTERS

(Jan. 28, 2016), http://www.reuters.com/article/us-roche-results-idUSKCN0V60SS; Christian Nordqvist, One Year on Herceptin for Breast Cancer Ideal, MED. NEWS TODAY (Oct. 1, 2012), http://www.medicalnewstoday.com/articles/250912.php.

118. Academic IP: Effects of University Patenting and Licensing on Commercialization and Research, NAT'L ACADS. BOARD ON SCI., TECH., \& ECON. POL'Y 261 (Apr. 17, 2001), http:/www.immagic.com/eLibrary/ARCHIVES/GENERAL/NACAD_US/N010417W.pdf.

119. Donald G. McNeil, Jr., Yale Pressed to Help Cut Drug Costs in Africa, N.Y. TimeS (Mar. 12, 2001), http:/www.nytimes.com/2001/03/12/world/yale-pressed-to-help-cut-drugcosts-in-africa.html.

120. Id.

121. Id.

122. Id; Additional Notes on Government Role in the Development of HIV/AIDS Drugs, CONSUMER PROJECT ON TECH. (Feb. 23, 2000), http://www.cptech.org/ip/health/aids /gov-role.html (showing government support for Yale research on the prescription).

123. McNeil Jr., supra note 119. 
before the price was lowered never saw the fruits of the claimed Bayh-Dole "benefit to humanity." 124

Overall, the picture of Bayh-Dole's impact on essential medicines reveals an arrangement that is problematic for taxpayers and patients, but exceedingly favorable for pharmaceutical corporations. As economist Marianna Mazzucato says, the U.S. "invests in the most uncertain stage of the business cycle and lets businesses hop on for the easier ride down the way." ${ }^{125}$ When the end of that ride features a government-granted monopoly market on a lifeor-death product, it is not surprising that the industry's profit margins are unsurpassed. 126

Nor is it surprising that Bayh-Dole's enabling of governmentfunded research to set the stage for private profit has negatively impacted medicine research in the private sector, which now spends more on marketing drugs than discovering them. ${ }^{127}$ Why spend corporate resources on research that taxpayers will conduct without cost to the corporation? The consulting firm Bain recently conducted a study that showed that top pharmaceutical corporations were earning more than 70 percent of their revenue from medicines that were developed elsewhere. ${ }^{128}$

This post-Bayh-Dole state of affairs in biomedicine has turned some supporters into critics. That includes the publication that was once the legislation's global cheerleader. The Economist s oft-quoted 2002 affection for the Act has significantly soured, as it published multiple articles in 2015 noting that the limited amount of impactful private pharmaceutical research has been coupled with access

124. History, U. ALLIED FOR ESSENTIAL MED., http://uaem.org/who-we-are/history/ (last viewed Feb. 11, 2017).

125. Marianna Mazzucato, The Entrepreneurial State: Debunking Public vs. PRIVATE SECTOR MYTHS 1 (rev. ed. 2015).

126. Richard Anderson, Pharmaceutical Industry Gets High on Fat Profits, BBC NEwS (Nov. 6, 2014), http://www.bbc.com/news/business-28212223; Liyan Chen, Best of the Biggest: How Profitable Are the World's Largest Companies?, FORBES (May 13, 2014), http://www.forbes.com/sites/liyanchen/2014/05/13/best-of-the-biggest-how-profitable-are-theworlds-largest-companies/\#4be1 dc6f4c33.

127. Is There a Cure for High Drug Prices?, CONSUMER ReP. (July 29, 2016), http:/www.consumerreports.org/drugs/cure-for-high-drug-prices/; GlobalData, Top 30 Pharma Companies Spent \$112 Billion on Research and Development in 2013, DRUG DEV. \& DELIVERY (Dec. 16, 2014), http://www.drug-dev.com/Main/Back-Issues/Top-30-PharmaCompanies-Spent-112-Billion-on-Resea-818.aspx; Anderson, supra note 126.

128. Nils Behnke et al., New Paths to Value Creation in Pharma, BAIN \& Co. (Sept. 24 2014), http://www.bain.com/publications/articles/new-paths-to-value-creation-in-pharma.aspx. 
problems. ${ }^{129}$ One of the articles concluded, "Ensuring that the benefits of greater research efficiency are fully passed on to governments and health insurers would require drastic changes, such as, say, abolishing the patent system and finding some other way to incentivize basic research." 130

\section{Has Bayh-Dole Had a Positive Impact on Academic Institutions and Research Priorities?}

The Bayh-Dole Act's positive impact on the pharmaceutical industry's bottom line is no surprise, especially in light of the industry's determined lobbying in support of the legislation. ${ }^{131}$ At the time, it seemed that there would be an even bigger winner under Bayh-Dole: the academic research institutions that would now be allowed to claim exclusive licenses for their federally-funded inventions. ${ }^{132}$ Yet there has been widespread criticism of Bayh-Dole's impact on the academy.

Historically, research at academic institutions was characterized by public dissemination of knowledge, an approach that is now characterized by the widely celebrated open source software movement. ${ }^{133}$ But Bayh-Dole shifted the university research focus toward the erection of patent walls around discovered knowledge and partnerships with for-profit corporations, including corporations created directly by university faculty to monetize their inventions. ${ }^{134}$ Many see this trend as a disturbing one and contrary to the timehonored educational mission of such institutions: "Instead of embodying open-knowledge commons, higher education risks becoming a propertied space where institutions predominantly view

129. Billion Dollar Babies, ECONOMIST (Nov. 28, 2015), http://www.economist.com /news/business/21679203-high-cost-rd-used-explain-why-drugs-giants-merge-and-why-theymust-charge [hereinafter Billion Dollar Babies]; A Question of Utility, ECONOMIST (Aug. 8, 2015), http://www.economist.com/node/21660559.

130. Billion Dollar Babies, supra note 129.

131. Drug Industry Influence Timeline, CTR. FOR PUB. INTEGRITY, https://www .publicintegrity.org/2005/07/07/5791/drug-industry-influence-timeline (last updated May 19, 2014).

132. The Bayh-Dole Act Research \& History Central - Founding Fathers - Howard Bremer, IP MALL, https://ipmall.law.unh.edu/content/bayh-dole-act-research-history-centralfounding-fathers-howard-bremer (last visited Feb. 15, 2017).

133. Mowery et al., supra note 94; Fiona Murray et al., Of Mice and Academics: Examining the Effect of Openness on Innovation, (Nat'1 Bureau of Econ. Research, Working Paper No. 14819), http://www.nber.org/papers/w14819.

134. So et al., supra note 93. 
their identities through a commercial lens," writes Jacob H. Rooksby in The Branding of the American Mind. ${ }^{135}$

There are data to support this concern, with academic researchers reporting significant pressure from university partner private corporations to hide information, suppress negative research results, and transfer patent ownership rights to companies in return for research-related gifts or support. ${ }^{136}$ The overall impact of the shift in university research priorities contributes to what Michael Heller and Rebecca Eisenberg have called the "anticommons," where profitmotivated patent thickets block the shared knowledge that helps spur scientific advancement. ${ }^{137}$ Perhaps even more concerning, universities' focus on the possibility of a patented pot of gold at the end of the research rainbow is demonstrably inattentive to aptlynamed "neglected diseases," which torment and even kill billions globally, but whose victims do not represent a lucrative market for a potential patented drug. ${ }^{138}$

Ironically, at the same time that Bayh-Dole's impact on university research culture has proven to be quite significant, the Act's impact on those institutions' bottom line is usually minimal. With the exception of a few blockbuster discoveries-such as UCLA's role in the Xtandi discovery as outlined in Section V-most universities collect very little net income from patents. ${ }^{139}$

135. See JaCob H. RoOKSBy, THE BRanding of the AMERICAN Mind: How Universities CAPTURe, MANAGE, AND MONETIZE INTELleCtUAL PROPERTY AND Why IT MATTERS (2006).

136. See, e.g., Adriane Fugh-Berman, How Basic Scientists Help the Pharmaceutical Industry Market Drugs, 4 PLOS BIOLOGY 11 (2013); JENNIFER WASHBURN, UNIVERSITY INC.: THE CORPORATE CORRUPTION OF Higher EDUCATION 352 (2005); Daniel S. Greenderg, Science for Sale: The Perils, Rewards, and Delusions of Campus CAPITALISM 288 (2007); David Blumenthal et al., Relationships Between Academic Institutions and Industry in the Life Sciences: An Industry Survey. 334 NEW ENG. J. MED. 368 (1996); Eric G. Campbell et al., Looking a Gift Horse in the Mouth: Corporate Gifts Supporting Life Sciences Research 279 JAMA 995 (1998).

137. Michael A. Heller \& Rebecca S. Eisenberg, Can Patents Deter Innovation? The Anticommons in Biomedical Research, 280 SCIENCE 698 (1998).

138. The Global Network for Neglected Tropical Diseases, SABIN VACCINE INST, http://www.sabin.org/programs/global-network-neglected-tropical-diseases-0 (last visited Feb. 13, 2017); Belen Pedrique et al., The Drug and Vaccine Landscape for Neglected Diseases (2000-11): A Systematic Assessment, 1 LANCET e37I (2013).

139. Richard Pérez-Peña, Patenting Their Discoveries Does Not Pay Off for Most Universities, a Study Says, N.Y. TIMES (Nov. 20, 2013), http://www.nytimes.com/2013/11 /21/education/patenting-their-discoveries-does-not-pay-off-for-most-universities-a-studysays.html; Heidi Ledford, Universities Struggle to Make Patents Pay, 501 NATURE 471 (2013), http://www.nature.com/news/universities-struggle-to-make-patents-pay-1.13811. 


\section{Petitions Filed for Federal Licensing Under the Bayh-Dole Act}

Despite the government retention of some licensing rights under Bayh-Dole, as described in Section II, and despite the ongoing availability crisis for federally-funded medicines described above, the U.S. government has never exercised its Bayh-Dole march-in rights. ${ }^{140}$ Before the Xtandi petition described in detail in Section VII, the U.S. National Institutes of Health had received and ruled on four march-in petitions.

In 1997, Cell-Pro, Inc. filed a march-in request on four patents for a cancer-fighting antibody. ${ }^{141}$ In 2004, Essential Inventions filed march-in requests for patents on an HIV/AIDS drug, ritonavir, after patent-holder Abbott Laboratories increased the drug's U.S. price by $400 \%$ in one day. ${ }^{142}$ That same year, Essential Inventions also requested march-in on the glaucoma drug latanoprost. Latanoprost was invented at Columbia University with federal funding and licensed to Pfizer, which sold the drug in the U.S. at a cost two to five times the price charged in other countries. ${ }^{143}$

140. Bayh-Dole does not establish any threshold for the government's contribution to the research that led to the final medicine before its retained rights become effective. Although corporate patent-holders do contribute to the later-stage development of medicines discovered with federal funding, it is clear there is no monetary threshold in the Act. As for whether retained rights apply only to discoveries where all applicable patents on the medicine trace back to government funding, that question is outside the scope of this article, especially since Xtandi's patents are all derived from federal funding. But the authors are persuaded that the Act does not require that $100 \%$ of the patents must come from a federally-funded source. $C f$. Aaron Kesselheim et al., The High Cost of Prescription Drugs in the United States Origins and Prospects for Reform, 316 JAMA 858 (2016) (taking the position that march-in rights can be used on "products that were developed in large part with government funding."). Compare University Research and the Patent System: Hearing Before the S. Comm. on the Judiciary, 110 th Cong. supra note 57 (testimony of Robert Weissman), and Mundy, supra note 60 (quoting James Love saying, "It doesn't matter if the government grant was for millions of dollars or for a few thousand."), with Engelberg \& Kesselheim, infra note 246. See generally Arno \& Davis, supra note 41 .

141. In the Case of Petition of CellPro, Inc., (Nat'l Inst. of Health Aug. 1, 1997) (determination), https:/www.ott.nih.gov/sites/default/files/documents/policy/cellpro-marchin .pdf.

142. In the Case of NORVIR® Manufactured by Abbott Laboratories, Inc., (Nat'l Inst. of Health July 29,2004 ) (determination), https://www.ott.nih.gov/sites/default/files/documents /policy/March-In-Norvir.pdf.

143. In the Case of Xalatan $($ Manufactured by Pfizer, Inc. (Nat'l Inst. of Health Sept. 17, 2004) (determination), https:/www.ott.nih.gov/sites/default/files/documents/policy/Marchin-xalatan.pdf; Jeff Gerth \& Sheryl Gay Stolberg, Drug Makers Reap Profits on Tax-Backed Research, N.Y. TIMES, Apr. 23, 2000, at Al. 
In 2010, three U.S. citizens with Fabry's disease filed a march-in request for the medicine fabrazyme, developed at the Mt. Sinai School of Medicine with NIH funding, and subsequently licensed to the corporation Genzyme. At the time the U.S. Fabry's patients filed their petition, they were being rationed at only 30 percent of the recommended dose. Newly-diagnosed patients were being denied the drug altogether. The petition to the NIH asked for the agency to exercise its Bayh-Dole march-in rights by licensing another manufacturer to make the drug and give a five percent royalty to the patent-holder. ${ }^{144}$

Each of the four petitions was denied, with the NIH specifically stating in the ritonavir and latanoprost cases that "the extraordinary remedy of march-in is not an appropriate means for controlling prices." ${ }^{145}$ The fabrazyme petition seemed to side-step that issue, since the concern was availability, not price: the drug developed by US funds was fully available to European patients even while U.S. patients were being turned away. ${ }^{146}$ But the NIH refused to act, suggesting that a different manufacturer would not get up to speed quickly enough to address the problem. ${ }^{147}$ The attorney who represented the petitioners, one of whom has since died from complications of the disease, says the fabrazyme ruling indicates the $\mathrm{NIH}$ has no intention of ever using Bayh-Dole to license generic drug manufacturing. "At this point, we know that those rights are legally worthless," he said. ${ }^{148}$

\section{E. The Pharmaceutical Industry's Relationship with Federal Health Agencies}

The attorney representing the Fabry's disease patients is not the only person frustrated with the legacy of Bayh-Dole. To some, the NIH refusal to exercise march-in rights in even a single instance in the thirty-six-year history of the Act, especially in the face of ongoing

144. Letter from John Brockman, President, Am. Med. Student Ass'n, et al. to Kathleen Sebelius, Secretary, Dept. of Health \& Human Services (Aug. 27, 2010), http://keionline.org/sites/default/files/amsa_kei_pc_pirg_uaem_Fabrazyme_letter_27aug2010. pdf [hereinafter Fabrazyme Request Letter].

145. See supra notes $142-143$.

146. Fabrazyme Request Letter, supra note 144.

147. See supra notes 142-144.

148. Fran Quigley, The \$100,000-Per-Year Pill: How US Health Agencies Choose Pharma Over Patients, TRUTHOUT (Aug. 5, 2016), http://www.truth-out.org/news/item/37111the-100-000-per-year-pill-how-us-health-agencies-choose-pharma-over-patients. 
medicine access crises, suggests the process is influenced by more than purely abstract statutory interpretation.

U.S. Representative Lloyd Doggett is one of many who points to the pharmaceutical industry's significant ties to the administrative agencies charged with administering the government-private industry dynamics initiated by Bayh-Dole. ${ }^{149}$ "To maintain its cozy relationship with the pharmaceutical industry, NIH has chosen to ignore price-gouging," Congressman Doggett said in 2016. "Taxpayers continue to fund research for too many drugs that too many cannot afford." 150

Doggett's reference to the relationship between NIH and the pharmaceutical industry invokes the industry's well-established role in Washington D.C. The industry is a prolific spender on both lobbying expenses and campaign contributions, and has more than 1,000 lobbyists working in Washington, D.C. alone. ${ }^{151}$ In addition, the key staff in the industry and at federal health departments share enough common backgrounds that observers complain about a "revolving door" between the corporations and the agencies tasked with regulating them. ${ }^{152}$ The Foundation of the NIH is managed by a board of directors stocked with pharmaceutical industry executives and lobbyists. ${ }^{153}$

In April of 2016, when NIH director Francis Collins was asked by Senator Richard Durbin at a Senate hearing why he was reluctant to exercise Bayh-Dole licensing rights, Collins replied that he feared doing so would harm the agency's relationship with the drug companies. ${ }^{154}$ Other NIH and Department of Defense staff has made

149. Id.

150. Id.

151. Top Industries, CTR. FOR RESPONSIVE POL., https://www.opensecrets.org/lobby top.php?indexType=i (last visited Feb.11, 2017).

152. Sheila Kaplan, From FDA Expert to Biotech Insider: The Drug Industry Thrives on the Revolving Door, STAT (Sept. 27, 2016), https://www.statnews.com/2016/09/27/fdabiopharama-revolving-door-study/; Revolving Door Between the US Government and Industry, CONSUMER PROJECT ON TECH. (Feb. 2006), http://www.cptech.org/ip/health/politics /revolvingdoor.html.

153. Board of Directors, FOUND. FOR NAT'L INST. HEALTH, http://www.fnih.org/about /directors (last viewed Feb. 11, 2017).

154. See Jeannie Baumann, NIH Pulls Back on Using Bayh-Dole for Drug Pricing, BLOOMBERG BUREAU NAT. AFF. (Apr. 8, 2016), https:/www.bna.com/nih-pulls-backn57982069624. 
it clear that they view march-in petitions as threats to the financial well-being of the pharmaceutical industry. ${ }^{155}$

The NIH also awards private companies exclusive licenses to some drugs it discovers in-house, and its process for doing so has been criticized as non-transparent and overly solicitous of corporate priorities. ${ }^{156}$ In one public statement that may have been more revealing than intended, a spokesperson for a company that received one of the licenses called his CEO's relationship with an NIH official an "asset." 157

One intellectual property scholar and attorney, Alfred Engelberg, has said that the current Bayh-Dole-created medicine research dynamic equates to an "unholy alliance" between the NIH, academic centers, and the pharmaceutical industry. ${ }^{158}$ The end result, he says, is socialized drug discovery leading to privatized profits. ${ }^{159}$ "The question here is, 'How stupid is the government?"' Engelberg says. "Billions of dollars in biomedical research is handed over to the industry with no strings attached, and then the government buys the majority of the output at the other end, with no price regulation." 160

\section{XTANDI AND THE BAYH-Dole ACT}

Xtandi is the brand name of the prescription drug enzalutimade. It is a synthetic, nonsteroidal pure antiandrogen that is used to treat an advanced and aggressive form of prostate cancer, metastatic castration-resistant prostate cancer (mCRPC). ${ }^{161}$ Castration resistant prostate cancer (CRPC) develops in ten to twenty percent of men with

155. Mundy, supra note 60.

156. See generally NIH Licenses (Patents, Data) and Comments on Proposed Exclusive Licenses, KNOWLEDGE ECOLOGY INT'L, http://keionline.org/nih-licenses (last viewed Feb. 11, 2017).

157. Zachary Brennan, NIH's Exclusive Licenses to Biotech, Pharma Start-Ups: Lots of Secrecy, Few Successes, REG. AFF. PROFS. SOC'Y (May 10, 2016), http://www.raps.org/Reg ulatory-Focus/News/2016/05/10/24906/NIH\%E2\%80\%99s-Exclusive-Licenses-to-BiotechPharma-Start-Ups-Lots-of-Secrecy-Few-Successes/.

158. Quigley, supra note 148.

159. Alfred Engelberg, How Government Policy Promotes High Drug Prices, HEALTH AFF.: HEALTH AFF. BLOG (Oct. 29, 2015), http://healthaffairs.org/blog/2015/10/29/howgovernment-policy-promotes-high-drug-prices/.

160. Quigley, supra note 148.

161. Letter from Knowledge Ecology Int'l and Union for Affordable Cancer Treatment to Sylvia Burwell, Sec'y, Dept. of Health \& Human Affairs, Francis Collins, Dir., Nat'1 Inst. of Health, and Ashton Carter, Sec'y, Dept. of Defense 16 (Jan. 14, 2016) [hereinafter Xtandi Petition]. 
prostate cancer within five years when the cancer progresses and the cells become castrate resistant and no longer receptive to traditional therapies. ${ }^{162}$ Xtandi is a new treatment option developed to combat this problem, meant to improve the quality of life and the life expectancy of patients diagnosed with $\mathrm{mCRPC}$, which ranges from nine to thirteen months. ${ }^{163}$

Xtandi is manufactured in $40 \mathrm{mg}$ oral tablets, with the typical dosage being four tablets per day. ${ }^{164}$ While five other CRPC treatment drugs exist, Xtandi is less invasive than the four other non-tablet form treatments and better tolerated than the only other oral tablet form treatment due to a lower toxicological profile. ${ }^{165}$

\section{A. The Discovery and Development of Xtandi}

Research and development of enzalutimade began in the early 2000 s at the University of California, Los Angeles (UCLA) with a team led by a chemist, Dr. Michael Jung, and an oncologist, Dr. Charles Sawyer. ${ }^{166}$ Xtandi has three patents listed in the FDA Orange Book, the book of approved drugs: 7709517 (diarylydantoin compounds), 8183274 (treatment of hyperproliferative disorders with diarylhydantoin), and 9126941 (treatment of hyperproliferative disorders with diarylhydantoin compounds). ${ }^{167}$ The U.S. provisional application for the invention was filed May 13, 2005, and the first patent application was filed a year later on May 15, 2006. The assignee for all three patents was The Regents of the University of California. ${ }^{168}$ Clinical trials for Xtandi commenced in July 2007. ${ }^{169} \mathrm{~A}$ total of four clinical trials were conducted, with the final one concluding in July 2012. ${ }^{170}$ After a priority review new drug

162. M. Kirby et al., Characterising the Castration-Resistant Prostate Cancer Population: A Systematic Review, 65 INT'L J. CLINICAL PRAC. 1180, 1183 (2011).

163. Suman Bhattacharya et al., Development of Enzalutamide for Metastatic Castration-Resistant Prostate Cancer, 1358 ANNALS N.Y. ACAD. SCI. 13 (2015).

164. Xtandi Petition, supra note 161 , at 4.

165. Id. at 11 (referring to the other treatment forms that are administered by IV, leukapheresis, or radiopharmaceuticals, whereas Xtandi and Zytiga are administered in pill form but Zytiga must be taken with prednisone, unlike Xtandi).

166. Xtandi-From Bench to Bedside, UCLA TECH. DEV. GRP., http://tdg.uclaoip.com/ xtandi $\% \mathrm{C} 2 \% \mathrm{AE}-\% \mathrm{E} 2 \% 80 \% 93$-bench-bedside (last visited Feb. 12, 2017).

167. Xtandi Petition, supra note 161, at 15.

168. See U.S. Patent No. 7,709,517 (filed May 15, 2006); U.S. Patent No. 8,183,274 (filed February 18, 2010); U.S. Patent No. 9,126,941 (filed Apr. 17, 2012).

169. Xtandi Petition, supra note 161 , at 18.

170. Id. 
application was filed May 22, 2012, to fast track the drug, Xtandi gained FDA approval August 31, 2012. ${ }^{171}$ Since obtaining initial FDA approval, multiple new clinical trials have commenced attempting to expand the use of enzalutamide for treatment of other cancers. ${ }^{1}$

\section{NIH and DoD Funding of Xtandi Research}

Original funding for research and development of Xtandi came from the United States federal government in the form of a National Institutes of Health (NIH) SPORE grant and a grant from the Department of Defense. ${ }^{173}$ As identified under the "government interests" section of each of the three patents for Xtandi at the U.S. Patent and Trademark Office, the U.S. government "has certain rights in the invention" because of the federal funding that helped lead to the invention. ${ }^{174}$

Federal funding was also involved at the clinical trial stage. Both Phase 1 and Phase 2 of clinical trials received funding from the National Cancer Institute and the Department of Defense. ${ }^{175}$ Additional funding was provided by several charitable organizations. ${ }^{176}$ The final two phases of trials were funded commercially through Medivation, Inc. and Astellas Pharma. ${ }^{177}$

171. U.S FOOD \& DRUG ADMIN., No. 2034150rigls000, SUMMARY REVIEW APPLICATION (Aug. 31, 2012), http://www.accessdata.fda.gov/drugsatfda_docs/nda/2012/20 3415Origls000SumR.pdf (stating May 22, 2012 as the date of submission); see also U.S FOOD \& DRUG ADMIN., Drug Approval Package (Sept. 12, 2012), http://www.accessdata.fda.gov /drugsatfda_docs/nda/2012/203415_xtandi_toc.cfm.

172. Xtandi Petition, supra note 161, at 12 (referring to "breast cancer ... hepatocellular carcinoma, bladder cancer, ovarian or fallopian tube cancer, pancreatic cancer, and Mantle Cell Lymphoma").

173. Xtandi Petition, supra note 161, at 11 (listing NIH grant number 5 P50 CA092131 and DOD grant number W81XWH-04-1-0129).

174. See U.S. Patents supra note 168.

175. Xtandi Petition, supra note 161 , at 18.

176. Id. at 11 ("For example, a 2009 paper in Science reporting on the development of MDV3100 (the development name for enzalutamide) acknowledged funding from the Prostate Cancer Foundation, the National Cancer Institute, the DOD PC051382 Prostate Cancer Research Program Clinical Consortium Award, and support from the Charles H. Revson Foundation. Likewise, a 2010 paper in the Lancet reporting on a critical Phase 1-2 trial acknowledges the financial support of Medivation, but also the Prostate Cancer Foundation, National Cancer Institute, the Howard Hughes Medical Institute, Doris Duke Charitable Foundation, and Department of Defense Prostate Cancer Clinical Trial Consortium.").

177. Id. at 18 . 


\section{University-Held Patents and Transfer of Licenses}

As discussed above, Xtandi patents were originally assigned to the Regents of the University of California because the discovery of the drug occurred at UCLA. On August 12, 2005, however, The Regents of the University of California entered into a licensing agreement with the biopharmaceutical company Medivation, Inc. and Medivation Prostate Therapeutics, Inc. (MPT), a subsidiary of Medivation, that gave MPT an exclusive worldwide license of the patents covering Xtandi. ${ }^{178}$ The licensing agreement obligated Medivation to pay an annual fee to The Regents of the University of California, as well as payments upon reaching milestone events, not to exceed $\$ 2.8$ million total, ${ }^{179}$ and royalty payments starting the year Xtandi became commercially sold. ${ }^{180}$

On October 26, 2009, when the drug was still in Phase 3 of clinical trials, Medivation entered into a collaboration agreement ${ }^{181}$ with Japanese pharmaceutical company Astellas Pharma Inc. that sublicensed Xtandi patent rights to Astellas. The goal of the agreement was to further commercialize and develop the drug. ${ }^{182}$ The UCLA licensing agreement was subsequently amended to include an additional payment requirement of ten percent of all income to Medivation under the Astellas collaboration agreement and four percent royalties on global net sales. ${ }^{183}$ Royalty payments to UCLA were to be split 50/50 between Medivation and Astellas, under the terms of the collaboration agreement, for Xtandi sales within the United States and Astellas assumed responsibility for royalty payments to UCLA for sales outside of the United States. ${ }^{184}$ The collaboration agreement also designated Astellas as the party responsible for all global manufacturing of Xtandi, giving Astellas the sole rights to distribution and sales of the drug. ${ }^{185}$ Medivation retained the right to market the drug jointly with Astellas within the United

178. Medivation, Inc., Annual Report (Form 10-K) (Feb. 21, 2013).

179. Paid in full as of Dec. 31, 2012. Id.

180. Exclusive License Agreement Between The Regents of The University of California and Medivation, Inc. and Medivation Prostate Therapeutics, Inc. (Aug. 12, 2005)

181. Collaboration Agreement (Oct. 26, 2009), available at https://www.sec.gov/ Archives/edgar/data/1011835/000119312510057020/dex 1015.htm.

182. Id.

183. Medivation, Inc., Annual Report (Form 10-K) (Feb. 26, 2016) [hereinafter Medivation 2016 Form 10-K].

184. Id. at 65.

185. Id. 
States. ${ }^{186}$ Additionally, under the collaboration agreement, Medivation and Astellas agreed to equally split all profits for U.S. sales. ${ }^{187}$ For sales outside of the U.S., Astellas agreed to pay royalties to Medivation. ${ }^{188}$

\section{a. Xtandi as Example of How Bayh-Dole has Transformed Discovery and Licensing}

Prior to the passage of the Bayh-Dole Act of 1980, an invention that was developed at a public university with federal government funding would likely be owned by the federal government. ${ }^{189}$ However, in an attempt to spur innovation, the Bayh-Dole Act authorizes the retention of ownership of the intellectual property rights by the inventors to financially incentivize private industry involvement and merely grants certain rights in the invention to the federal government, such as a royalty-free nonexclusive license or Section 203 march-in rights. This means that universities and forprofit entities are now able to make enormous profits from inventions that are funded with taxpayer dollars.

Xtandi provides an instructive example. The impact of the BayhDole Act on university-developed inventions can be clearly demonstrated through its creation. It arose from a mix of university and industry research and development, originally conducted by university researchers and government funding, but industry investment and involvement increased as the drug proved its potential success and value through clinical trials. Once UCLA discovered the drug, two of the inventors made an arrangement with the pharmaceutical industry, via a licensing agreement with Medivation, to bring the drug to market. ${ }^{190}$ Medivation sponsored the first two clinical trials, but in combination with more federal funding. ${ }^{191}$

With clinical trial results looking bright for Xtandi, Medivation partnered with Astellas to manufacture and commercialize the drug through an additional sublicensing agreement. ${ }^{192}$ After two more

186. Id. at 24 .

187. Id. at 53 .

188. Id.

189. Ritchie de Larena, supra note 3, at 1378.

190. Xtandi Petition, supra note 161 , at 14.

191. Id. at 18 .

192. See Stuart Wolpert, Astellas, Medivation to Develop, Commercialize MDV3100 for Treatment of Prostate Cancer, UCLA NEWSROOM (Nov. 4, 2009), http://newsroom.ucla .edu/releases/astellas-and-medivation-enter-111920. 
clinical trials, Astellas submitted a new drug application to the FDA and obtained FDA approval several months later. ${ }^{193}$ Outside of the funding from the federal government, Xtandi research and development was made possible with investments from Medivation and Astellas totaling approximately $\$ 724.5$ million as of $2015 .{ }^{194}$ Xtandi sales began in the United States, following FDA approval, at the end of 2012. ${ }^{195}$ Sales of Xtandi outside of the United States started $\operatorname{mid} 2013 .{ }^{196}$

UCLA has benefitted greatly from the discovery of Xtandi and its commercial success. By licensing the intellectual property rights in Xtandi to Medivation and its sub-licensee Astellas, the university was able to remove itself from further development of the drug while still earning revenue from it. UCLA earned $\$ 2.8$ million, plus annual maintenance payments, plus ten percent of Medivation's income from Astellas under the collaboration agreement, plus four percent royalty payments from global net sales. ${ }^{197}$ Medivation's income from Astellas through the collaboration agreement reached $\$ 665$ million as of December 31, 2015. ${ }^{198}$ A dispute has arisen over the exact amount of that sublicensing income that UCLA is entitled to under the agreement, and litigation has ensued. ${ }^{199}$ However, according to Medivation, $\$ 32$ million has been paid to UCLA as of the first quarter of $2016 .{ }^{200}$

In an attempt "to provide stability and minimize risk associated with the volatility of the pharmaceutical industry marketplace," UCLA decided to sell its royalty rights in Xtandi to Royalty Pharma, a privately held New York based pharmaceutical company, on March $4,2016 .^{201}$ The university received approximately $\$ 520$ million from the transaction, which it has invested in a portfolio designed to allow payouts of roughly $\$ 60$ million per year through 2027 . The goal of the

193. Xtandi Petition, supra note 161 , at 17

194. Calculated based on Xtandi Petition, supra note 161, figures plus the Medivation 2016 Form 10-K, supra note 183 which listed Medivation direct costs as $\$ 74,616,000$ and Astellas cost share of $\$ 60.8 \mathrm{M}$.

195. Xtandi Petition, supra note 161 , at 10

196. Id.

197. Medivation 2016 Form $10-\mathrm{K}$, supra note 183 , at 8 .

198. Id. at 60.

199. Id. at 65.

200. Id.

201. See Phil Hampton, UCLA Sells Royalty Rights Connected with Cancer Drug to Royalty Pharma, UCLA NEWSROOM (Mar. 4, 2016), http://newsroom.ucla.edu/releases/uclasells-royalty-rights-connected-with-cancer-drug-to-royalty-pharma. 
fund is to provide additional research funding for the school, as well as student scholarships. ${ }^{202}$

It is evident from the history of Xtandi how the Bayh-Dole Act has changed the landscape of how inventions are developed and ultimately commercialized. UCLA, Medivation, and Astellas, among others, have benefited exponentially from federally-funded research. The Bayh-Dole Act made it so that huge economic incentives were necessary to induce industry involvement and bring Xtandi fully to market.

\section{The XTANDi AVailability Crisis}

Currently, in the United States, the cost for a one-year course of treatment of Xtandi per patient is roughly $\$ 129,269 .{ }^{203}$ This price point is the highest of any country in the world. As such, it is having negative repercussions on patient access to the drug and inhibiting availability simply because the drug is unaffordable. Its cost is a heavy burden to the Medicare program and other federal healthcare programs; but it is also putting a large strain on private insurance plans, to the point that some insurers are cutting off patient access altogether. Research data has demonstrated that its price has increased every year since Xtandi gained FDA approval in 2012, which could signify that these barriers to access due to price will endure unless something is done. ${ }^{204}$

\section{A. Costs to Medicare and other Federal Programs}

On average, prostate cancer diagnoses occur at the age of 66 when the individual is already eligible for or enrolled in Medicare. ${ }^{205}$ Because of this, Medicare is responsible for around $68.6 \%$ of overall U.S. Xtandi sales. ${ }^{206}$ In 2015, total Medicare spending for Xtandi was an enormous $\$ 790,655,731.47 .^{207}$ The average cost per pill was

202. Id.

203. Xtandi Petition, supra note 161 , at 4 (referring to the Apr. 2015 U.S. AWP of $\$ 88.48 \times 4$ pills per day $\times 365.25$ days).

204. Id. at 10 (Table 4.2).

205. Id at 9 .

206. Medicare spent $\$ 790,655,731.47$ on Xtandi in 2015 and overall US Xtandi sales totaled $\$ 1,151,317,000$ according to Medivation, Inc., Annual Report (Form 10-K) (Feb. 25, 2015).

207. Medicare Spending Dashboard 2015, CTRS. FOR MEDICARE AND MEDICAID SERVS., https://www.cms.gov/Research-Statistics-Data-and-Systems/Statistics-Trends-and-Re ports/Dashboard/2015-Medicare-Drug-Spending/medicare-drug-spending-dashboard-2015- 
$\$ 73.94 .^{208}$ This was a seven percent increase from the 2014 Medicare price of $\$ 69.41,{ }^{209}$ making the average cost to Medicare for a one year course of treatment approximately $\$ 108,026.34$. Medicare beneficiaries receiving Xtandi treatment in 2015 reached 16,912, with their cost share totaling nearly $\$ 42.5$ million. ${ }^{210}$ With the United States baby boomer population aging, the number of Medicare beneficiaries needing Xtandi could continue to rise, placing further monetary burden on the system. ${ }^{211}$

Some Medicare beneficiaries are low income and eligible to receive both Medicare and Medicaid benefits. Individuals that qualify for both benefits are known as dual-eligibility beneficiaries and receive low income subsidies to help them afford treatment. ${ }^{212}$ While the exact amount that Medicaid pays for Xtandi is unknown at this time, it appears that Medicaid also pays some of the high cost of the drug, at least in the dual-eligibility category. Published Medicare data for 2015 indicated that the cost share of Xtandi for a Medicare beneficiary was $\$ 3,081.14$, whereas the cost share of Xtandi for a Medicare beneficiary receiving a low-income subsidy was $\$ 178.81 .{ }^{213}$ Again, the exact amount paid by Medicaid is unknown, but this $\$ 2,902.43$ difference suggests that the price of Xtandi is having a significant impact on Medicaid spending, also.

The Department of Veterans Affairs has the potential to be impacted by the exorbitant price of Xtandi, as well. A study conducted in 2013 indicated that Vietnam and Korean veterans with possible Agent Orange exposure face an increased risk of prostate cancer. ${ }^{214}$ At this time, however, Xtandi/enzalutamide is not included on the VA National formulary, ${ }^{215}$ meaning that it would have to be

data.html (last visited Feb. 12, 2017).

208. Id.

209. Id.

210. Id.

211. Xtandi Petition, supra note 161 , at 9.

212. DuAl Eligible BENEFICIARIES UNDER THE MEDICARE AND MEDICAID PROGRAMS 3 (2017), https://www.cms.gov/Outreach-and-Education/Medicare-Learning-Net work-MLN/MLNProducts/downloads/Medicare_Beneficiaries_Dual_Eligibles_At_a_Glance .pdf

213. Medicare Spending Dashboard 2015, supra note 207.

214. Xtandi Petition, supra note 161, at 9 (citing Nathan Ansbaugh et al., Agent Orange as a Risk Factor for High-Grade Prostate Cancer, 119 CANCER 2399 (July 1, 2013)).

215. See VA Formulary Search, U.S. DEPT. OF VETERANS AFF. http://www.pbm.va.gov /apps/vanationalformulary/ (In Search For field, enter "Xtandi"). 
specially requested and approved. ${ }^{216}$ Astellas has contracted with the VA to provide enzalutamide through October 14, 2018, though. ${ }^{217}$ The price per dosage is currently listed at $\$ 42.38 .{ }^{218}$

\section{B. Lack of Access to Patients in Private Insurance Plans}

Patients covered under private insurance plans face even greater access barriers to Xtandi. The April 2015 average wholesale price of the drug was $\$ 88.48$ per pill, making a full year's treatment approximately $\$ 129,269$ in the United States. ${ }^{219}$ This is a price difference of double to quadruple the prices paid by similarly situated high-income countries, such as those in Europe or Canada and Australia. ${ }^{220}$

Due to the excessive pricing in the Unites States, private insurance companies are trying to restrict access to the drug. Restricted access is achieved by requiring prior authorization by the insurer before treatment can begin or by utilizing a tier system that places that drug on one of the tiers with the highest co-pays, effectively increasing the cost burden of the beneficiary. ${ }^{221}$ At an extreme, some health plans may soon follow in the footsteps of CVS Health, who will remove Xtandi from its formulary in February 2017 in an attempt to control health plan costs. ${ }^{222}$ Restrictive access policies are detrimental because if access is restricted due to of the cost of the drug, it is ultimately the patient's health that suffers.

There are currently three FDA approved prostate cancer treatment drugs that are the leading prescription choices of doctors in the United States. ${ }^{223}$ Oncologists might make clinical determinations to prescribe Xtandi over the other two when treating patients with certain drug sensitivities. ${ }^{224}$ Studies have shown that Xtandi should be

216. Veterans Affairs National Formulary Frequently Asked Questions, U.S. DEPT. OF VETERANS AFF., http:/www.pbm.va.gov/pbm/nationalformulary/vanationalformularyfrequent lyaskedquestions.pdf (last visited Feb. 13, 2017).

217. Pharmaceutical Catalog Search, U.S. DEPT. OF VeTERANS AfF., https://www.va .gov/nac/Pharma/List (last visited Feb. 13, 2017).

218. Id.

219. Xtandi Petition, supra note 161, at 4.

220. Id. at 5 (Table 1.1).

221. Id. at 6.

222. See Robert Langreth, CVS Cuts Coverage of Dozens of Drugs in Exclusion Expansion, BLOOMBERG (Aug. 2, 2016), https://www.bloomberg.com/news/articles/2016-08$02 /$ cvs-plans-to-bar-novartis-cancer-drug-from-2017-covered-drugs.

223. Xtandi Petition, supra note 161 , at 5.

224. Id. at 6. 
the first form of treatment if it is to be maximally effective. ${ }^{225}$ If a patient takes one of the other two prostate cancer drugs prior to starting Xtandi, it is possible that the patient develops a resistance to Xtandi and is unable to receive its full effectiveness. ${ }^{226}$ In some patients, complete resistance to Xtandi can develop. ${ }^{227}$ Thus, it is problematic if a health insurance plan requires a patient to fail other forms of prostate cancer treatment before being allowed to begin treatment with Xtandi, which is exactly what occurs when a patient is forced to receive prior authorization. The insurer is limiting patient choice and access to Xtandi solely based on the price and without regard to the negative health implications for the patient.

\section{U.S. GOVERNMENT RESPONSE TO XTANDI CRISIS}

On January 14, 2016 two non-profit organizations, Knowledge Ecology International (KEI) and the Union of Affordable Cancer Treatment (UACT), petitioned the National Institutes of Health (NIH), Department of Defense (DoD), and Department of Health and Human Services (HHS) to use their power under the Bayh-Dole Act to make Xtandi available to the public on reasonable terms. ${ }^{228}$ Additionally, several attempts were made by various members of Congress urging the agencies to offer further guidance and clarification on the Act. ${ }^{229}$ The petition was eventually denied roughly five months later, however.

225. Id. (citing Tian Zhang et al., Enzalutamide Versus Abiraterone Acetate for the Treatment of Men with Metastatic Castration-Resistant Prostate Cancer, 16 EXPERT OPINION ON PHARMACOTHERAPY 473-85 (Mar. 2015)).

226. Id.

227. Id. (discussing Schrader et al. study where $48.6 \%$ of patients who took other two drugs were completely resistant to Xtandi) (citing Andres Jan Schrader et al., Enzalutamide in Castration-Resistant Prostate Cancer Patients Progressing After Docetaxel and Abiraterone, 65 EUR. UROLOGY 30 (2014)).

228. Id. at 2.

229. See Letter from U.S. Congress to Sylvia Burwell, Secretary, Dep't of Health \& Human Servs., and Francis Collins, Director, Nat'l Inst. of Health (Jan. 11, 2016), https://www.keionline.org/wp-content/uploads/2017/10/Doggett-51 member-MarchIn11Jan2016.pdf; see also Letter from U.S. Congress to Sylvia Burwell, Secretary, Dep't of Health \& Human Servs., and Francis Collins, Director, Nat'1 Inst. of Health (Mar. 28, 2016), https:/www.keionline.org/wp-content/uploads/2017/10/congressional-letter-to-nih-and-hhsregarding-xtandi.pdf [hereinafter March Congressional Letter]. 


\section{A. Congressional Requests to NIH and HHS}

Several days prior to the submission of the Xtandi petition, more than fifty members of Congress sent a letter to Secretary Burwell of HHS and Director Collins of NIH asking that the agencies use "[their] existing statutory authority" under the Bayh-Dole Act to address rising drug prices in the US. ${ }^{230}$ The letter specifically suggested that the NIH use its power to compel a patent holder of a federally-funded new drug to issue its license to a third party in order to reduce prices. ${ }^{231}$ The congressmembers further requested that the agencies offer greater guidance that better detail circumstances in which the agencies would be willing to exercise their statutory authority since they had declined to do so at every instance in the past. ${ }^{232}$ Their premise was that if the agencies clarified the Act and their utilization of the same, then pharmaceutical companies would feel increased pressure to cease their price gouging practices because they would know with greater specificity what constitutes egregious and unreasonable drug pricing that would trigger agency intervention. ${ }^{233}$

A few months later, on March 28, 2016, six members of the House of Representatives, this time joined by six Senators, wrote again to the Secretary and Director. ${ }^{234}$ The letter called for the NIH to conduct a public hearing concerning the Xtandi petition, similar to the one previously granted by the agency in 2004 when it was determining whether to exercise its march-in rights for the pricing of Norvir. ${ }^{235}$ They reiterated the agencies' long-standing, yet unused, authority under the Act, and argued that drug pricing can be an impediment to access and thus prices should be considered when deciding a drug's availability on reasonable terms. ${ }^{236}$

Additionally, during the first-half of 2016, lawmakers took advantage of opportunities to question both Secretary Burwell and Director Collins regarding their respective agencies' stance on the Xtandi petition and their authority under the Bayh-Dole Act while testifying before Congress. ${ }^{237}$ Both parties were reluctant to offer

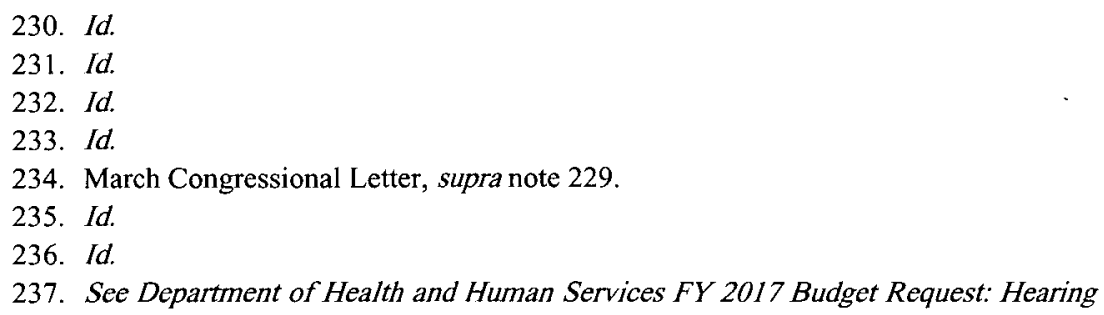


congressmen much help, though, but rather kept conversation on the topic to a bare minimum. Further discussion on their responses is addressed below.

\section{B. Xtandi Petition to NIH, DoD, and HHS under Bayh-Dole}

As aforementioned, KEI and the UACT sent a petition to NIH, DoD, and HHS in January 2016 urging the agencies to use the statutory rights granted to them under the Bayh-Dole Act and force Xtandi to be manufactured at a reasonable price that would not inhibit access of the drug by cancer patients. First, the petition asked that the agencies exercise their royalty-free rights in the three patents for the drug as listed in the FDA Orange Book or, in the alternative, grant the organizations' petition for march-in rights. ${ }^{238}$ Second, the petition more broadly requested the agencies to implement policy for the utilization of royalty-free rights or march-in rights in cases of egregious drug pricing by pharmaceutical companies, such as when "prices in the United States are excessive, and/or higher than they are in high income foreign countries.",239

The petition emphasized the exorbitant price of Xtandi in the United States compared to other similarly situated countries, asserting that Astellas was taking advantage of the US drug market in its pricing of Xtandi because of the federal agencies' repeated refusal to step in. ${ }^{240}$ It also highlighted the toll that the price was taking on the cancer patients that needed access to the drug and on the American taxpayer through Medicare payments. Moreover, the petition underscored the unreasonableness of allowing Astellas to sell Xtandi in the United States at the highest price point in the world when it was the United States that provided the funding for the research and development of the drug. ${ }^{241}$ Excessive pricing of federally funded inventions, it argued, was exactly what the Bayh-Dole Act was intended to protect against and such pricing should be taken into account when deciding whether it is available to the public on reasonable terms. ${ }^{242}$

Before H. Comm. on Ways and Means, 114th Cong. (2016); see also Departments of Labor, Health and Human Services, Education, and Related Agency Appropriations for 2017: Hearings Before a Subcomm. of the H. Comm. on Appropriations, 114th Cong. (2016).

238. Xtandi Petition, supra note 161 , at 2.

239. Id.

240. Id. at 4

241. Id. at 25.

242. Id. 


\section{Offer by Generic Manufacturer}

Also of note is an April 22, 2016 offer from the President of Biolyse Pharma to Director Collins and the Administrator for the Centers of Medicare and Medicaid Services (CMS) to manufacture the generic version of Xtandi (enzalutamide) for $\$ 3.00$ per pill. ${ }^{243}$ Biolyse Pharma is a Canadian drug company that specializes in developing and manufacturing cancer treatment drugs. ${ }^{244}$ In her offer letter, the president of the company stated that if NIH exercised its march-in rights on Xtandi, Biolyse could have the generic version of the drug FDA approved within three years and supply the generic to Medicare at a mere four percent of the price that Astellas had Xtandi set for Medicare in 2014. ${ }^{245}$ If accepted, Biolyse's pricing offer would have the potential to save the United States government over $\$ 57,000$ annually per patient. ${ }^{246}$

\section{Government Responses}

Secretary Burwell first acknowledged receipt of the January $11^{\text {th }}$ Congressional letter when Representative Lloyd Doggett (D-Tex.) pointedly asked her about it while she was testifying before the House Ways and Means Committee nearly a month later on February 10, 2016. ${ }^{247}$ When Representative Doggett inquired about the consideration the letter had received, Secretary Burwell responded: "Your letter we have received, thank you, and we are continuing to try and pursue every administrative option. We've proposed legislative and statutory changes as a part of the budget, but are looking at a wide array, of which we welcome your letter and your suggestions. $" 248$

243. Letter from Brigitte Kiecken, President, Biolyse Pharma, to Andy Slavitt, Acting Administrator, Ctrs. for Medicare and Medicaid Servs. (Apr. 22, 2016), https://www.keionline .org/wp-content/uploads/2017/10/BiolysePharma-letter-CMS-22April2016.pdf.

244. Overview, BIOLYSE PHARMA, http://www.biolyse.com/english.html (last visited Feb. 12, 2017).

245. Zach Struver, Biolyse Pharma Offers to Supply Enzalutamide (Xtandi) for $\$ 3$ per pill to Medicare and Developing Countries, KNOWLEDGE ECOLOGY INT'L (Apr. 27, 2016), http://keionline.org/node/2480.

246. Alfred B. Engelberg \& Aaron S. Kesselheim, Use the Bayh-Dole Act to Lower Drug Prices for Government Healthcare Programs, 22 NATURE MED. 576 (2016).

247. John M. Clerici \& Phillip Bradley, Federal Govemment Won't March In When It Comes to Drug Prices, Law 360 (July 11, 2016), https://www.law360.com/articles/815909 /federal-gov-t-won-t-march-in-when-it-comes-to-drug-prices.

248. Id.; Ways and Means Hearing, supra note 237. 
However, an official response from the Secretary came by way of a letter on March 2, 2016. In it, she declined the Congressional request for clarification and guidance on the Act, stating that "after consulting with the NIH, we believe the statutory criteria are sufficiently clear and additional guidance is not needed." 249 She further added that the NIH evaluated the decision to exercise its statutory march-in rights under the Bayh-Dole Act on a "case-by-case basis" and would march in "if presented with a case where the statutory criteria are met regarding commercialization and use of an NIH-funded, patented invention, and where march-in could in fact alleviate health or safety needs of address a situation where effective steps are not being taken to achieve practical application of the inventions." 250

Director Collins responded separately on March 16, 2016 at a House Appropriations Committee hearing when questioned by Representative Rosa DeLauro (D-Conn.) after she renewed her pleas for NIH to exercise march-in rights to combat rising drug prices of federally funded drugs. ${ }^{251}$ Specifically, she asked the Director twice to define the meaning of "reasonable terms." ${ }^{252}$ Without supplying Representative DeLauro with an exact definition, Director Collins instead circled back to Secretary Burwell's earlier response and reiterated that the agency would march in if reasonable terms were not met and that the agency made such a determination on a case-bycase basis. ${ }^{253}$

The following month, when Director Collins was testifying before a panel at a Senate Appropriations hearing, he encountered further inquiry about drug pricing by Senator Richard Durbin (DIII.). ${ }^{254} \mathrm{He}$ seemed to take a step back this time, however, and told the Senator that although the agency determined whether reasonable terms were being met on a case-by-case basis, he had since had the opportunity to review the Bayh-Dole Act and he was not under the

249. Letter from Sylvia M. Burwell, Secretary, Dept. of Health \& Human Servs., to Lloyd Doggett, Representative, U.S. House of Representatives (Mar. 2, 2016), http://freepdf hosting.com/be $7532 \mathrm{cfc} 0$. pdf.

250. Id.

251. Departments of Labor, Health and Human Services, Education, and Related Agency Appropriations for 2017: Hearings Before a Subcomm. of the H. Comm. on Appropriations, 114th Cong. 7 (2016).

252. Id. at 25-26.

253. Id.

254. Jeannie Baumann, NIH Pulls Back on Using Bayh-Dole for Drug Pricing, BLOOMBERG (Apr. 20, 2016), https://www.bna.com/nih-pulls-back-n57982069624/. 
impression that pricing was to be included as criteria for deciding availability on reasonable terms. ${ }^{255} \mathrm{He}$ interpreted it, rather, to mean that a "product was unavailable simply because it was not being commercialized." 256 The Director also mentioned he worried about alienating the agency from the pharmaceutical industry and new innovation by utilizing the Act. ${ }^{257}$

On June 7, 2016, Secretary Burwell wrote to Representative Doggett to inform him that the agencies would not be holding a public hearing regarding the Xtandi petition as the congressmen had asked. ${ }^{258}$ She declared that the NIH could acquire adequate information by adhering to 37 CFR 401.6 and that it did not necessitate conducting a public hearing. ${ }^{259}$

Finally, on June 20, 2016, Director Collins issued a response to Andrew Goldman of KEI regarding the Xtandi petition. ${ }^{260} \mathrm{NIH}$ denied it on the grounds that it had found Xtandi to be "broadly available as a prescription drug" and that the petition "provide[d] no information and no information was identified from public sources to suggest that enzalutamide is currently or will be in short supply." ${ }^{261}$ The Director had obviously adhered to the same premise that he had espoused at the hearing several months prior when he indicated that he did not believe that pricing should be taken into consideration when determining availability on reasonable terms.

\section{CONCLUSION}

The plain language and clear legislative intent of the Bayh-Dole Act shows that the U.S. government has the right to march in and license federally-funded inventions when those inventions are not available to the public on reasonable terms, or if health and safety needs require that licensing. In response to the current medicines

255. F.Y. 2017 Budget for National Institutes of Health: Hearing Before the S. Comm. on Appropriations, Subcomm. on Labor, Health and Human Services, Education, and Related Agencies, 114th Cong. (2016) (statement of Francis Collins, Director, Nat'l Inst. of Health).

256. Id.

257. Id.

258. Letter from Sylvia M. Burwell, Secretary, Dept. of Health \& Human Services, to Lloyd Doggett, Representative, U.S. House of Representatives (June 7, 2016).

259. Id.

260. See Letter from Francis S. Collins, Director, Nat'l Inst. of Health, to Andrew S. Goldman, Counsel, Knowledge Ecology Int'l (June 20, 2016), https://www.keionline.org/wpcontent/uploads/2017/10/Final-Response-Goldman-6.20.2016.pdf.

261. Id. at 1. 
access crisis, as demonstrated by the exorbitant cost and limited availability of the federally-funded medicine Xtandi, the U.S. needs to finally exercise its rights that have lain dormant since the Act was passed in 1980 . 


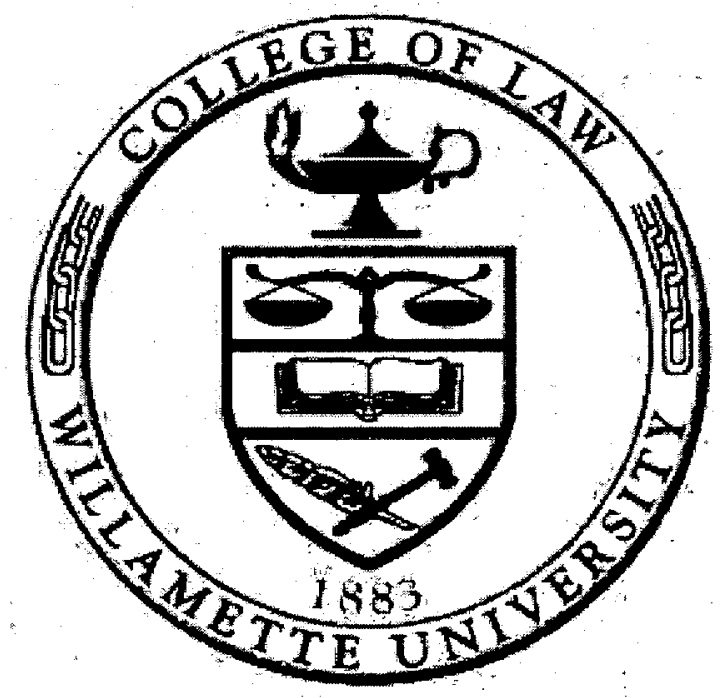

